\title{
Direct-Acting Oral Anticoagulants and Their Reversal Agents-An Update
}

\author{
Stephanie A. Kustos and Pius S. Fasinu * \\ Department of Pharmaceutical Sciences, College of Pharmacy \& Health Sciences, Campbell University, \\ Buies Creek, NC 27506, USA; sakustos0927@email.campbell.edu \\ * Correspondence: fasinu@campbell.edu
}

Received: 12 September 2019; Accepted: 14 October 2019; Published: 15 October 2019

check for updates

\begin{abstract}
Background: Over the last ten years, a new class of drugs, known as the direct-acting oral anticoagulants (DOACs), have emerged at the forefront of anticoagulation therapy. Like the older generation anticoagulants, DOACs require specific reversal agents in cases of life-threatening bleeding or the need for high-risk surgery. Methods: Published literature was searched, and information extracted to provide an update on DOACS and their reversal agents. Results: The DOACs include the direct thrombin inhibitor-dabigatran, and the factor Xa inhibitors-rivaroxaban, apixaban, edoxaban, and betrixaban. These DOACs all have a rapid onset of action and each has a predictable therapeutic response requiring no monitoring, unlike the older anticoagulants, such as warfarin. Two reversal agents have been approved within the last five years: idarucizumab for the reversal of dabigatran, and andexanet alfa for the reversal of rivaroxaban and apixaban. Additionally, ciraparantag, a potential "universal" reversal agent, is currently under clinical development. Conclusions: A new generation of anticoagulants, the DOACs, and their reversal agents, are gaining prominence in clinical practice, having demonstrated superior efficacy and safety profiles. They are poised to replace traditional anticoagulants including warfarin.
\end{abstract}

Keywords: andexanet alfa; anticoagulation; apixaban; betrixaban; dabigatran; direct oral anticoagulants; edoxaban; idarucizumab; rivaroxaban

\section{Introduction}

Maintaining the physiologic and therapeutic balance between coagulation and bleeding is necessary for cardiovascular health and sustenance of body functions. This delicate balance is a result of complex physiologic and biochemical processes which, when disrupted, can lead to fatal consequences, such as thrombosis or bleeding [1]. The coagulation cascade, through the interaction of various proteins, clotting factors, and platelets (Figure 1), functions to prevent blood loss in cases of vascular injury. 
Intrinsic Pathway

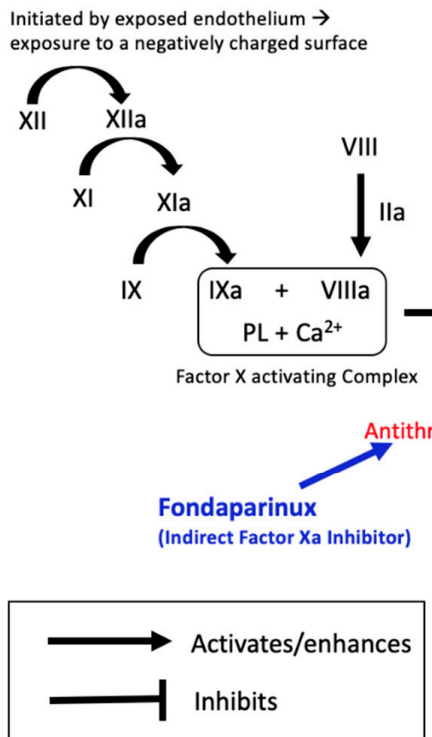

\section{Extrinsic Pathway}

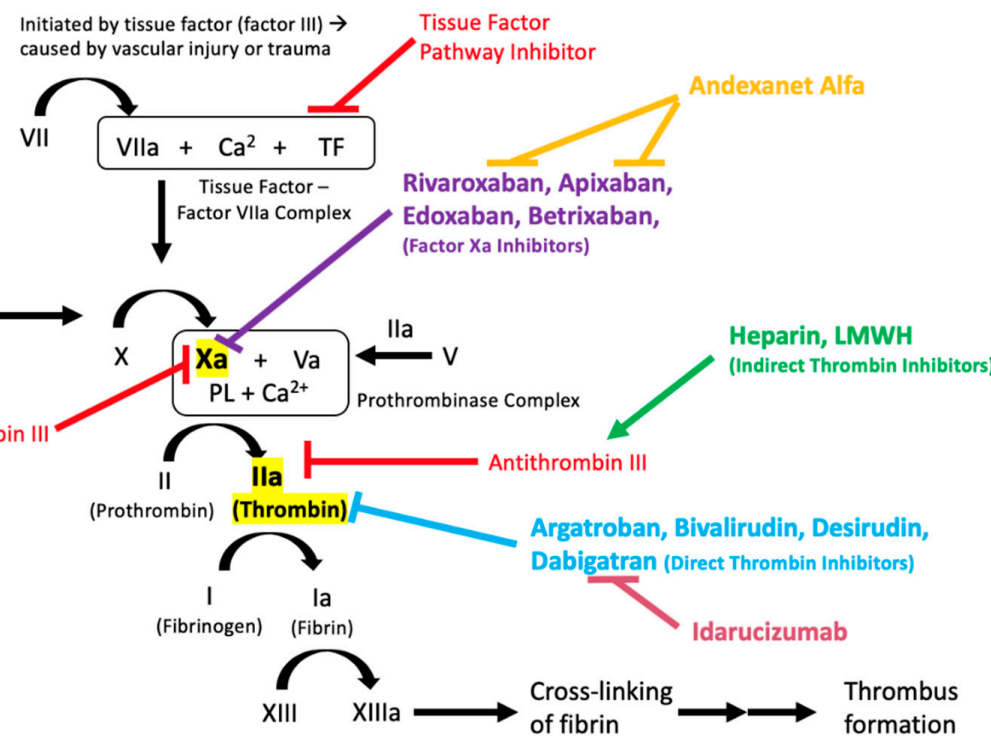

Figure 1. Overview of the coagulation cascade, indicating the sites of action of anticoagulant medications and their reversal agents.

Anticoagulants are important drugs used as the primary intervention for the prevention and treatment of thrombosis (Table 1). Unfractionated heparin (UFH) and low-molecular weight heparin (LMWH) are often used in acute thrombosis because of their rapid onset of action and effectiveness [2]. UFH and LMWH bind and activate antithrombin, which acts to inhibit factor IIa (thrombin) and factor Xa, inhibiting further progression of the clotting cascade [3]. As a result of this, heparins are considered indirect anticoagulants. Heparins are only bioavailable through parenteral administration, thus excluding the option of easy self-administration. This, in addition to the need to monitor activated partial thromboplastin time (aPTT) (especially with UFH), the risk of heparin-induced thrombocytopenia (HIT), risk of major bleeding episodes, and increased risk of osteoporosis and vertebral fractures, form the major limitations associated with heparin and LMWH therapy. Reversal of these agents is usually not required due to their relatively short half-lives. However, in severe bleeding cases, protamine sulfate is an effective reversal agent for both UFH and LMWH [4]. 
Table 1. Overview of available anticoagulant medications.

\begin{tabular}{|c|c|c|c|c|c|}
\hline $\begin{array}{c}\text { General } \\
\text { Class/MOA }\end{array}$ & $\begin{array}{l}\text { Drug Name and Year } \\
\text { of First Approval }\end{array}$ & Labeled Indications & $\begin{array}{c}\text { Adult Dosing } \\
\text { (with Normal Renal \& Hepatic Function) }\end{array}$ & $\begin{array}{c}\text { Route of } \\
\text { Administration }\end{array}$ & $\begin{array}{c}\text { Approved } \\
\text { Reversal Agent }\end{array}$ \\
\hline $\begin{array}{l}\text { Vitamin } \mathrm{K} \\
\text { Antagonist }\end{array}$ & $\begin{array}{l}\text { Warfarin } \\
(1954)\end{array}$ & $\begin{array}{l}\text { - VTE prophylaxis and treatment (associated } \\
\text { with Afib or cardiac valve replacement) } \\
\text { Adjunct to reduce the risk of systemic } \\
\text { embolism after MI }\end{array}$ & $\begin{array}{c}\text { INR-adjusted-based dosing } \\
\text { Goal INR is 2-3 for most patients } \\
\text { Goal INR for mitral valve replacement is } 2.5-3.5\end{array}$ & Oral & $\begin{array}{l}\text { Vitamin K and/or } \\
\text { Prothrombin } \\
\text { Complex } \\
\text { Concentrate }\end{array}$ \\
\hline \multirow{2}{*}{$\begin{array}{l}\text { Indirect } \\
\text { Thrombin } \\
\text { Inhibitors }\end{array}$} & $\begin{array}{l}\text { Heparin } \\
(1940 \mathrm{~s})^{*}\end{array}$ & $\begin{array}{l}\text { - VTE prophylaxis and treatment (associated } \\
\text { with thromboembolic disorders or Afib) } \\
\text { Prevention of clotting in arterial or } \\
\text { cardiac surgery } \\
\text { - Anticoagulant for extracorporeal circulation or } \\
\text { dialysis procedures }\end{array}$ & $\begin{array}{c}\text { VTE Treatment: } \\
80 \text { unit } / \mathrm{kg} \text { IV bolus, then } 18 \text { unit } / \mathrm{kg} / \mathrm{h} \text { IV infusion } \\
\text { VTE Prophylaxis: } \\
5000 \text { units q8h } \\
\text { Target anti-Xa level } 6 \mathrm{~h} \text { post-dose: } \\
0.3-0.7 \text { units } / \mathrm{mL}\end{array}$ & $\begin{array}{c}\text { Injectable } \\
\text { Intravenous or } \\
\text { Subcutaneous }\end{array}$ & $\begin{aligned} & \text { Protamine } \\
\rightarrow & 100 \% \text { reversal }\end{aligned}$ \\
\hline & $\begin{array}{l}\text { Low Molecular Weight } \\
\text { Heparins (LMWH): } \\
\text { - } \quad \text { Dalteparin (1994) } \\
\text { - } \quad \text { Enoxaparin (1993) } \\
\text { - } \quad \text { Tinzaparin (2000) }\end{array}$ & $\begin{array}{l}\text { - VTE prophylaxis (in hip, knee, abdominal, } \\
\text { thoracic, cardiac, or neuro surgery; in patients } \\
\text { with restricted mobility; trauma; pregnancy) } \\
\text { Thrombosis treatment and secondary } \\
\text { prophylaxis (wide variety of indications) } \\
\text { Thromboprophylaxis in acute coronary } \\
\text { syndrome (unstable angina, NSTEMI, STEMI) } \\
\text { or cardioversion in Afib/atrial flutter }\end{array}$ & $\begin{array}{c}\text { DVT Treatment: } \\
1 \mathrm{mg} / \mathrm{kg} \text { q12h OR } 1.5 \mathrm{mg} / \mathrm{kg} \text { q } 24 \mathrm{~h} \\
\text { VTE Prophylaxis: } \\
40 \mathrm{mg} \text { q24h } \\
\text { Target anti-Xa level } 4 \mathrm{~h} \text { post-dose: } \\
0.5-1.1 \text { units } / \mathrm{mL}\end{array}$ & $\begin{array}{c}\text { Injectable } \\
\text { Subcutaneous }\end{array}$ & $\begin{aligned} & \text { Protamine } \\
\rightarrow & 60 \% \text { reversal }\end{aligned}$ \\
\hline \multirow{2}{*}{$\begin{array}{l}\text { Direct } \\
\text { thrombin } \\
\text { Inhibitors }\end{array}$} & $\begin{array}{l}\text { Argatroban } \\
\quad(2000)\end{array}$ & $\begin{array}{l}\text { - Prophylaxis or treatment of thrombosis in } \\
\text { patients with HIT } \\
\text { - Anticoagulant for percutaneous coronary } \\
\text { intervention (PCI) }\end{array}$ & $\begin{array}{l}\text { Prophylaxis/treatment of thrombosis in HIT: } \\
2 \mathrm{mcg} / \mathrm{kg} / \mathrm{min} \text { and adjust based on aPTT (goal } \\
1.5-3 \text { times baseline) } \\
\text { PCI: } 350 \mathrm{mcg} / \mathrm{kg} \text { bolus, then } 25 \mathrm{mcg} / \mathrm{kg} / \mathrm{min} \\
\text { infusion and adjust based on ACT }\end{array}$ & $\begin{array}{l}\text { Injectable } \\
\text { Intravenous }\end{array}$ & $\mathrm{N} / \mathrm{A}$ \\
\hline & $\begin{array}{l}\text { Bivalirudin } \\
\quad(2000)\end{array}$ & $\begin{array}{l}\text { - Anticoagulant for percutaneous coronary } \\
\text { intervention (PCI), including patients with HIT }\end{array}$ & $\begin{array}{c}\text { Before PCI: } \\
0.1 \mathrm{mg} / \mathrm{kg} \text { bolus, then } 0.25 \mathrm{mg} / \mathrm{kg} / \mathrm{h} \text { until PCI } \\
\text { During PCI: } \\
0.75 \mathrm{mg} / \mathrm{kg} \text { bolus, then } 1.75 \mathrm{mg} / \mathrm{kg} / \mathrm{h} \text { for the } \\
\text { duration of procedure }\end{array}$ & $\begin{array}{l}\text { Injectable } \\
\text { Intravenous }\end{array}$ & N/A \\
\hline
\end{tabular}


Table 1. Cont

\begin{tabular}{|c|c|c|c|c|c|}
\hline $\begin{array}{c}\text { General } \\
\text { Class/MOA }\end{array}$ & $\begin{array}{l}\text { Drug Name and Year } \\
\text { of First Approval }\end{array}$ & Labeled Indications & $\begin{array}{c}\text { Adult Dosing } \\
\text { (with Normal Renal \& Hepatic Function) }\end{array}$ & $\begin{array}{c}\text { Route of } \\
\text { Administration }\end{array}$ & $\begin{array}{c}\text { Approved } \\
\text { Reversal Agent }\end{array}$ \\
\hline & $\begin{array}{l}\text { Dabigatran } \\
\quad(2010)\end{array}$ & $\begin{array}{l}\text { - VTE treatment \& prevention in patients who } \\
\text { have been treated with a parenteral } \\
\text { anticoagulant for } 5 \text { to } 10 \text { days } \\
\text { - VTE prophylaxis in total hip arthroplasty } \\
\text { (THA) } \\
\text { - Stroke prevention in Afib }\end{array}$ & $\begin{array}{c}\text { VTE Treatment (after initial therapy with a } \\
\text { parenteral anticoagulant for } 5 \text { days): } 150 \mathrm{mg} \text { BID } \\
\text { Afib: } 150 \mathrm{mg} \text { BID } \\
\text { THA: } 110 \mathrm{mg} \text { given } 1-4 \text { h after surgery, then } \\
220 \mathrm{mg} \text { QD for } 10-14 \mathrm{~d}\end{array}$ & Oral & $\begin{array}{l}\text { Idarucizumab } \\
\text { (Praxbind) }\end{array}$ \\
\hline & $\begin{array}{l}\text { Desirudin } \\
\quad(2003)\end{array}$ & - $\quad$ DVT prophylaxis in hip-replacement surgery & $15 \mathrm{mg} \mathrm{q} 12 \mathrm{~h}$ & $\begin{array}{c}\text { Injectable } \\
\text { Subcutaneous }\end{array}$ & $\mathrm{N} / \mathrm{A}$ \\
\hline & $\begin{array}{l}\text { Lepirudin } \\
\text { (1998) }\end{array}$ & $\begin{array}{ll}- & \text { HIT } \\
- & \text { Prevention of VTE in patients with HIT }\end{array}$ & $\begin{array}{l}0.4 \mathrm{mg} / \mathrm{kg} \text { IV bolus, followed by } 0.15 \mathrm{mg} / \mathrm{kg} / \mathrm{h} \mathrm{IV} \\
\text { infusion for } 2-10 \text { days (or as clinically indicated) }\end{array}$ & $\begin{array}{c}\text { Injectable } \\
\text { Subcutaneous }\end{array}$ & N/A \\
\hline $\begin{array}{l}\text { Indirect Factor } \\
\text { Xa Inhibitor }\end{array}$ & $\begin{array}{l}\text { Pentasaccharide-Fondapari } \\
\text { (2001) }\end{array}$ & $\begin{array}{ll}\text { - inux } & \text { DVT or PE treatment in conjunction } \\
\text { - } & \text { with warfarin } \\
& \text { VTE prophylaxis in surgical patients }\end{array}$ & $\begin{array}{l}\text { VTE Treatment: } \\
<50 \mathrm{~kg} \rightarrow 5 \mathrm{mg} \text { QD } \\
50-100 \mathrm{~kg} \rightarrow 7.5 \mathrm{mg} \text { QD } \\
>100 \mathrm{mg} \rightarrow 10 \mathrm{mg} \text { QD } \\
\text { VTE Prophylaxis: } \\
2.5 \mathrm{mg} \text { QD }\end{array}$ & $\begin{array}{c}\text { Injectable } \\
\text { Subcutaneous }\end{array}$ & N/A \\
\hline \multirow[t]{2}{*}{$\begin{array}{l}\text { Factor Xa } \\
\text { Inhibitors }\end{array}$} & $\begin{array}{l}\text { Apixaban } \\
\text { (2012) }\end{array}$ & $\begin{array}{l}\text { - Treatment of VTE and to reduce recurrence of } \\
\text { VTE following initial therapy } \\
\text { - Prevention of stroke and systemic embolism } \\
\text { in NVAF } \\
\text { - Prophylaxis of VTE post-op in hip or } \\
\text { knee arthroplasty }\end{array}$ & $\begin{array}{l}\text { VTE Treatment: } 10 \mathrm{mg} \text { BID for } 7 \text { days, then } \\
55 \mathrm{mg} \text { BID } \\
\text { Afib: } 5 \mathrm{mg} \text { BID; if patient has any } 2 \text { of the } \\
\text { following then } 2.5 \mathrm{mg} \mathrm{BID} \rightarrow \text { age } \geq 80 \text {, weight } \\
\leq 60 \mathrm{~kg} \text {, or SCr } \geq 1.5 \mathrm{mg} / \mathrm{dL} \\
\text { Knee/hip arthroplasty: } 2.5 \mathrm{mg} \text { BID starting } \\
12-24 \mathrm{~h} \text { after surgery } \\
\text { Secondary prevention: } 2.5 \mathrm{mg} \text { BID (following } \\
6 \text { months of initial therapy) }\end{array}$ & Oral Tablet & Andexanet Alfa \\
\hline & $\begin{array}{l}\text { Betrixaban } \\
\text { (2017) }\end{array}$ & - $\quad$ Prophylaxis of VTE in medical patients & $\begin{array}{l}\text { VTE prophylaxis: } 160 \mathrm{mg} \text { as a single dose on day } \\
\text { 1, followed by } 80 \mathrm{mg} \text { once daily for } 35 \text { to } 42 \text { days }\end{array}$ & Oral Capsule & N/A \\
\hline
\end{tabular}


Table 1. Cont.

\begin{tabular}{|c|c|c|c|c|c|}
\hline $\begin{array}{l}\text { General } \\
\text { Class/MOA }\end{array}$ & $\begin{array}{l}\text { Drug Name and Year } \\
\text { of First Approval }\end{array}$ & Labeled Indications & $\begin{array}{c}\text { Adult Dosing } \\
\text { (with Normal Renal \& Hepatic Function) }\end{array}$ & $\begin{array}{c}\text { Route of } \\
\text { Administration }\end{array}$ & $\begin{array}{c}\text { Approved } \\
\text { Reversal Agent }\end{array}$ \\
\hline & $\begin{array}{l}\text { Edoxaban } \\
\quad(2015)\end{array}$ & $\begin{array}{l}\text { - Treatment and prevention of recurrent VTE } \\
\text { following 5-10 days of } \\
\text { parenteral anticoagulant } \\
\text { - Prevention of stroke and systemic embolism } \\
\text { in NVAF }\end{array}$ & $\begin{array}{c}\text { VTE: } \\
\text { If }>60 \mathrm{~kg} \rightarrow 60 \mathrm{mg} \text { QD } \\
\text { If } \leq 60 \mathrm{~kg} \rightarrow 30 \mathrm{mg} \text { QD } \\
\text { Afib: } 60 \mathrm{mg} \text { QD }\end{array}$ & Oral Tablet & N/A \\
\hline & $\begin{array}{l}\text { Rivaroxaban } \\
\quad(2011)\end{array}$ & $\begin{array}{ll}\text { - } & \text { Treatment of VTE } \\
\text { - } & \text { Prophylaxis of VTE in total hip or } \\
\text { knee arthroplasty } \\
\text { - } \\
\text { Prevention of stroke and systemic embolism } \\
\text { in NVAF } \\
\text { - } \quad \text { Reduce the risk of cardiovascular events in } \\
\text { CAD or PAD } \\
\text { - Indefinite anticoagulation to reduce the risk of } \\
\text { recurrent VTE }\end{array}$ & $\begin{array}{l}\text { VTE treatment: } 15 \mathrm{mg} \text { BID w/ food for } 21 \text { days, } \\
\text { followed by } 20 \mathrm{mg} \text { QD w/ food } \\
\text { Knee/hip arthroplasty: } 10 \mathrm{mg} \text { QD starting 6-10 h } \\
\text { after surgery } \\
\text { Afib: } 20 \mathrm{mg} \text { QD w/ evening meal } \\
\text { CAD/PAD: } 2.5 \mathrm{mg} \text { BID (with or without aspirin) } \\
\text { Secondary prevention: } 10 \mathrm{mg} \text { QD (following } \\
6 \text { months of initial treatment) } \\
\text { Indefinite anticoagulation: reduced } \\
\text { intensity dosing }\end{array}$ & Oral Tablet & Andexanet Alfa \\
\hline
\end{tabular}

* Heparin was first described as being an effective anticoagulant as early as 1916, and was grandfathered in after the establishment of the USFDA. ** Bayer, the pharmaceutical company that produced lepirudin, stopped further production of the drug since May 31, 2012. Abbreviations: VTE = venous thromboembolism; Afib = atrial fibrillation; MI = myocardial infarction; DVT = deep vein thrombosis; PE = pulmonary embolism; STEMI = ST-elevated myocardial infarction; NSTEMI = non-ST-elevated myocardial infarction; HIT = heparin-induced thrombocytopenia; $\mathrm{CAD}=$ coronary artery disease; $\mathrm{PAD}=$ peripheral artery disease Note: VTE includes DVT and PE. 
Direct thrombin inhibitors (DTIs), including argatroban, bivalirudin, desirudin, and lepirudin, are US-FDA-approved alternative parenteral anticoagulants. While bleeding is the most common complication associated with DTI use, no specific reversal agent is currently available [5].

Vitamin K antagonists are available for oral administration. They exert pharmacological activity by inhibiting vitamin $\mathrm{K}$ epoxide reductase (VKORC1), an enzyme required to convert vitamin $\mathrm{K}$ to its reduced and active form. The reduced form of vitamin $\mathrm{K}$ acts as a cofactor for gamma-glutamyl carboxylase, an enzyme that is responsible for activating vitamin-K dependent clotting factors (II, VII, IX, X). By inhibiting VKORC1, vitamin K antagonists, such as warfarin, indirectly inhibit the activation of clotting factors II, VII, IX, and X [6]. In addition to the narrow therapeutic index, inter-individual variability in response to warfarin therapy is a major challenge in dosing. Therefore, it is necessary to monitor the international normalized ratio (INR) and adjust the dose of warfarin accordingly. Achieving and maintaining the appropriate INR range is often complicated by external factors, such as diet and drug- or herb-related interactions. Bleeding associated with warfarin is relatively common, and in severe cases, warfarin therapy can be reversed through the administration of vitamin $\mathrm{K}$, fresh frozen plasma (FFP), prothrombin complex concentrate (PCC), or recombinant factor VIIa (rFVIIa) [7].

Recent advancement in drug development has led to the approval of direct-acting oral anticoagulants (DOACs), including direct anti-IIa (dabigatran etexilate) and direct anti-Xa anticoagulants (apixaban, betrixaban, edoxaban, and rivaroxaban). Along with warfarin, the DOACs are now the mainstay of anticoagulant therapy in outpatient settings. DOACs, in particular, have become preferred over warfarin in the prevention and treatment of thromboembolic disorders, primarily because of their proven efficacy, superior safety records, and more predictable and reliable pharmacokinetic and pharmacodynamic profiles [8]. Additionally, the DOACs do not have a requirement for routine coagulation monitoring. DOACs are preferred over VKAs for VTE treatment and prevention, and for stroke prevention in patients with nonvalvular atrial fibrillation (NVAF) [9]. While DOACs have many favorable characteristics, they have limitations. Apart from the cost, bleeding risk is still a major concern. Although there is a believed upward trend in the number of patients reporting bleeding after taking DOACs, several studies, including a systemic review and meta-analysis of existing data, have shown that bleeding rates are actually much lower with DOACs than those associated with VKAs [10-13].

As a new class of drugs, DOACs require the use of specific reversal agents in cases of life-threatening bleeding or the need for high-risk surgery. Clinicians are still getting acquainted with different approaches to reverse a DOACs' anticoagulant activity. Therefore, the aim of this study is to provide an updated review on DOACs and their reversal agents based on current literature, guidelines, and recommendations.

\section{Materials and Methods}

This is a non-structured narrative review conducted to provide an overview and update on direct oral anticoagulants and their reversal agents. The review was conducted by searching PubMed, Medline, Cochrane, Web of knowledge, Google Scholar, and Clinicaltrials.gov databases for original studies, case reports, clinical guidelines, and clinical trial reports on DOACs and their reversal agents using relevant search terms and the combinations thereof, including individual anticoagulants, reversal agents, and pharmacological classes. The reference list of retrieved review papers and meta-analyses were also used to identify relevant publications. Inclusion was limited to publications available in the English language.

\section{Results}

Over the last ten years, five DOACs have been FDA-approved, including dabigatran, rivaroxaban, apixaban, edoxaban, and betrixaban. Additionally, two new reversal agents have been FDA-approved within the last five years, specifically for the indication of reversing the effects of some of the DOACs. 


\subsection{Before the Advent of Approved Reversal Agents}

Various approaches and interventions were utilized to reverse the effects of DOACs before the approval of specific reversal agents. A typical representation of these approaches is presented in Figure 2 [14]. The methods chosen were based on the severity of the DOAC-induced hemorrhage. The success of such measures largely depended on the time the anticoagulant was last administered, the dose administered, concurrent medications, the site of the bleed, and the patient's co-morbidities. Treatment could be divided into tiers based on the severity of the bleed and the offending agent.

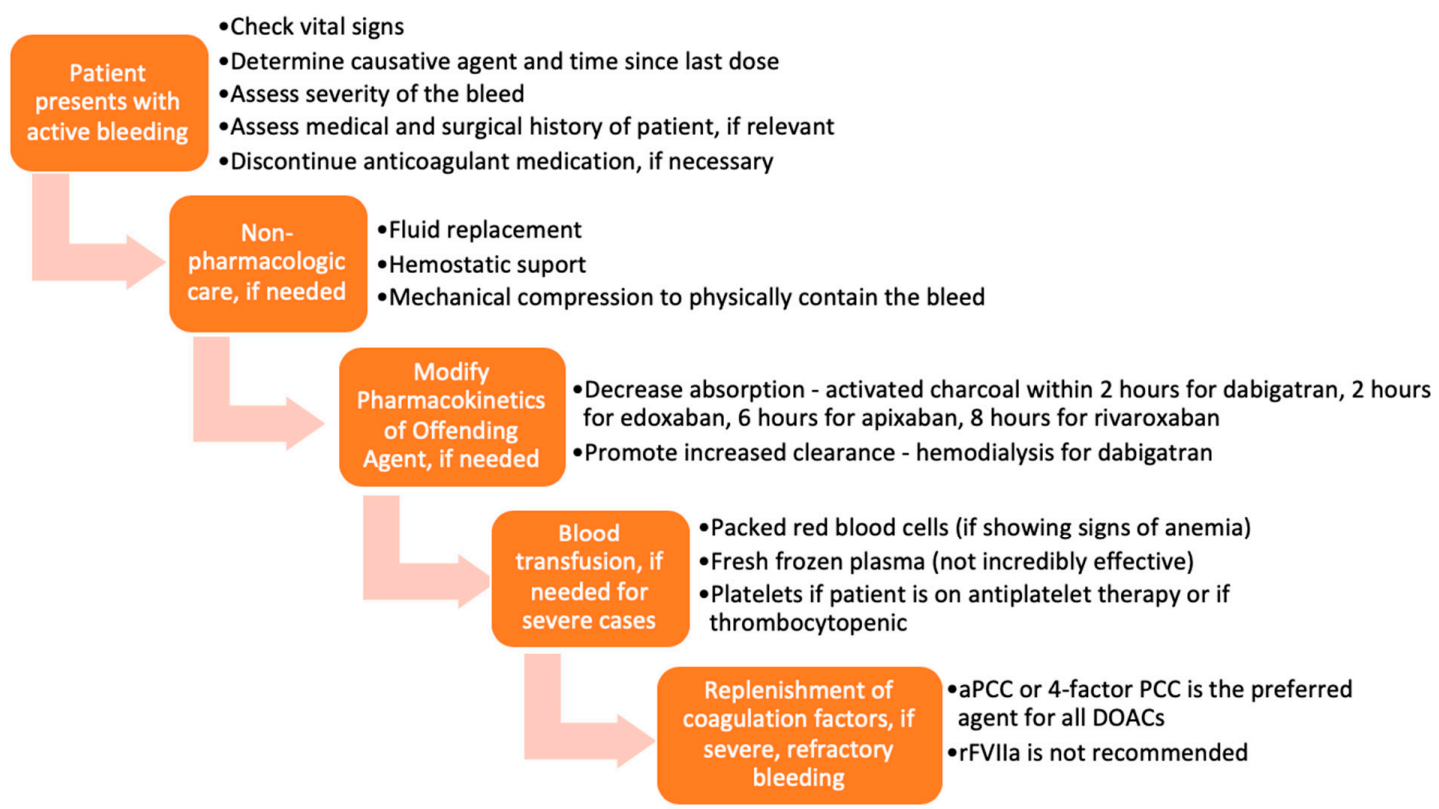

Figure 2. Flow chart of management of bleeding, before the approval of idarucizumab and andexanet alfa.

In mild or moderate DOAC-induced bleeding, the standard of care was to delay or withhold subsequent administration of the drug [15]. However, in severe bleeding, more aggressive supportive interventions, including blood transfusions and mechanical compression, were employed [16,17]. Timely administration of activated charcoal (within $2 \mathrm{~h}$ of edoxaban [18,19], $6 \mathrm{~h}$ of apixaban [20], or 8 $\mathrm{h}$ of rivaroxaban [21] use) has been shown to significantly reduce DOAC absorption. Enhancement of clearance through hemodialysis was a particularly useful option for dabigatran, as it is not highly protein-bound and is mainly cleared by the kidneys [22,23]. Hemodialysis has not been shown to be effective in reversing apixaban and rivaroxaban [15,24].

Several studies have also examined the use of blood products and coagulation factor replenishment, such as prothrombin complex concentrates (PCC), fresh frozen plasma (FFP), and activated recombinant factor VII (rFVIIa) for the reversal of anticoagulation induced by DOACs [25-28]. FFP is unlikely to be useful in reversing the DOACs because, as shown in studies, the replenishment of coagulation factors is not sufficient to reverse the direct effects of DOACs on factor IIa and factor Xa [14,29-32]. PCC is the most widely used and most effective of these blood products for DOAC-related bleeding. More specifically, studies have demonstrated that activated PCC (factor eight inhibitor bypassing activity (FEIBA)) or 4-factor PCC are the preferred agents for DOAC-induced anticoagulation reversal before the approval of specific antidotes [32]. Tranexamic acid has been widely used to manage bleedings-drug-induced or otherwise-with great success [33].

Each of the strategies discussed has a particular place in therapy. Even though specific reversal agents have been developed and are currently under development, non-pharmacologic measures are always important first steps in the therapy for a bleed. 


\subsection{Direct Thrombin Inhibitor-Dabigatran-And Its Reversal}

Dabigatran etexilate is currently the only oral direct thrombin inhibitor available. Approved in 2010, dabigatran is indicated for VTE treatment and secondary prophylaxis in patients who have been treated with a parenteral anticoagulant for 5 to 10 days, VTE prophylaxis in total hip arthroplasty (THA), and stroke prevention in patients with atrial fibrillation [34].

Dabigatran etexilate is a pro-drug, and is converted to its active form, dabigatran, by nonspecific esterases in the plasma, gut, and liver, after being rapidly absorbed [35-37]. Dabigatran has a quick onset of action of $0.5-2 \mathrm{~h}$ with a half-life of about $12 \mathrm{~h}$ [38]. The active drug exerts its effects by binding directly to the active site of thrombin [39]. This reversible binding renders thrombin inactive, including both unbound thrombin and fibrin-bound thrombin [40]. The inhibition of thrombin prevents the conversion of fibrinogen to fibrin and ultimately leading to the inhibition of clot formation (Figure 1).

Dabigatran is only partially metabolized by the liver and undergoes glucuronidation $(<10 \%)[41]$. Studies have confirmed this by demonstrating that hepatic impairment only slightly affected the amount of active drug in the body [42]. Dabigatran is primarily eliminated by the kidneys (up to 80\%), so renal impairment impacts dabigatran elimination more than hepatic impairment does. Since the elimination of dabigatran is highly dependent on the kidneys, it is not recommended in patients with severe renal impairment $(\mathrm{CrCl}<30 \mathrm{~mL} / \mathrm{min})$, as accumulation of the drug could occur [43].

The metabolism of dabigatran etexilate is mediated primarily by esterases, while CYP450 enzymes play no relevant role [37]. Therefore, drug interactions due to CYP enzymes are not anticipated. As a substrate for p-glycoprotein, dabigatran is predisposed to drug interactions with p-glycoprotein substrates (i.e., digoxin), inhibitors (i.e., amiodarone, verapamil, ketoconazole) or inducers (i.e., rifampicin, phenytoin, phenobarbital, carbamazepine), which may put patients at risk for thrombosis or severe bleeding [44].

Dabigatran is contraindicated in patients with active bleeding or with mechanical prosthetic heart valves [34]. Dose-related adverse reactions have been seen with dabigatran, including gastrointestinal disturbances, reported in $25-40 \%$ of patients [45,46].

Being a direct thrombin inhibitor, dabigatran causes bleeding with reported incidence of 11-19\%, and $2 \%$ life-threatening incidences [47]. The long duration of action often complicates the need for emergency surgery, as studies have shown that dabigatran must be discontinued at least $24 \mathrm{~h}$ before surgery (or $48 \mathrm{~h}$ for procedures associated with a high bleeding risk) for patients with normal renal function. If renal function is compromised, dabigatran should be discontinued even earlier [48].

Before the approval of specific antidotes, pharmacologic options, such as recombinant factor VIIa (rFVIIa) or prothrombin complex concentrates (PCC), were considered for life-threatening hemorrhage following dabigatran use $[49,50]$. However, these agents showed conflicting evidence of efficacy, and were never approved for this indication.

Idarucizumab (aDabi-Fab), an antibody specific to dabigatran, was developed, and was demonstrated to bind to dabigatran in a way that was structurally similar to dabigatran-thrombin association. Functional clotting assays as well as platelet aggregation studies showed that idarucizumab had no effect on coagulation tests, did not enhance the generation of thrombin, and neither increased nor decreased platelet aggregation [51].

Early studies suggested that idarucizumab was safe and capable of reversing dabigatran effects within one minute and maintaining such effect for the duration of the infusion ( 25 min) [51,52]. The only limitation was the saturation of the antibody, possibly requiring another dose. A two-part phase I clinical trial of idarucizumab examined its proof-of-concept and determined appropriate dosing [53]. The proof-of-concept study examined the effects of idarucizumab in 47 healthy male volunteers who were randomized to receive varying doses of idarucizumab two hours after the final dose of a 4-day dabigatran pre-treatment. Idarucizumab was found to reverse the effects of dabigatran in a dose-dependent manner, with no serious adverse events reported. Mild adverse events, such as infusion site reactions in a few participants and one episode of epistaxis, were reported in the 
idarucizumab group. However, there was no difference in the incidence of adverse events between the treatment and placebo groups, indicating tolerability of this reversal agent [53].

In the phase III clinical trial, REVERSE-AD, idarucizumab was efficacious in reversing the anticoagulant effects of dabigatran [54-56]. This open-label study included a total of 503 patients divided into two groups: patients with uncontrollable or life-threatening bleeding due to dabigatran and patients who needed to undergo an invasive procedure that required the reversal of dabigatran. The primary end point in this clinical trial was the maximum percentage of reversal of dabigatran anticoagulant effects within four hours of idarucizumab administration. Patients received a total of $5 \mathrm{~g}$. of idarucizumab, consisting of two 2.5-g boluses administered less than $15 \mathrm{~min}$ apart. Within four hours, the medium maximum reversal was $100 \%$, and in most patients, the reversal was sustained for at least $24 \mathrm{~h}$, independent of renal function, age, or sex. In the bleeding group, $67.7 \%$ of the patients had stopped bleeding within $24 \mathrm{~h}$, with the other $32.3 \%$ of patients being "undetermined". In the group of patients about to undergo a procedure, $93.4 \%$ were regarded as having normal hemostasis. The mortality rate was $\sim 19 \%$ in both groups, and thrombotic adverse events were reported in $4.8 \%$ of patients within 30 days, and in $6.8 \%$ of patients within 90 days. The relatively high mortality rate and incidence of thrombotic events were attributed to multiple factors, including the age of the participants (median age 78) and their multiple comorbid conditions. Also, all of the thrombotic events that occurred within $72 \mathrm{~h}$ after idarucizumab administration were due to failure to re-initiate anticoagulation. During this study, anti-idarucizumab antibodies were also discovered in a small percent of patients $(5.6 \%)$, with two-thirds of these patients having pre-existing antibodies that were cross-reactive with idarucizumab. This phenomenon needs to be examined further. Overall, this phase III clinical trial was one of the main studies that enhanced the regulatory approval by the USFDA of idarucizumab for dabigatran reversal [57].

Approved in 2015, idarucizumab is effective and specifically indicated for dabigatran-related life-threatening or uncontrollable bleeding as well as for the reversal of dabigatran in the event of an emergency surgery requirement [58-60]. The approved dose is two 2.5-g IV bolus infusions administered within 15 min [61].

Apart from being the only approved drug for the reversal of dabigatran effect, idarucizumab's rapid onset of action and ready-to-use formulation (precluding reconstitution) make it user-friendly in an emergency. However, there are limitations and cautions in idarucizumab use. It is thermolabile and photosensitive, and therefore requires stringent storage conditions. Unopened vials in original packaging are only stable for $48 \mathrm{~h}$ at room temperature. Once exposed to light, idarucizumab must be used within six hours [62]. Another drawback of idarucizumab is thrombosis risk. Post-marketing reports described events such as acute ischemic stroke, deep vein thrombosis, pulmonary embolism, myocardial infarction, intracardiac thrombus, right heart failure, and other thromboembolic complications [63].

With limited post-approval use data, idarucizumab has shown great effectiveness in the majority of the patient population. However, there have been cases of therapeutic failure with the drug. A case report detailed an unsuccessful reversal of dabigatran by idarucizumab in two different patients who had high concentrations of dabigatran [64]. One patient had an emergency surgery and experienced bleeding, while the other patient simply had severely elevated concentrations of dabigatran. Both were refractory to idarucizumab as well as other non-specific reversal strategies, and both cases ultimately resulted in death. It is important to note, however, that both patients had complex medical conditions that contributed to their hemostasis imbalance. Another example of therapeutic failure was in the case of an 87-year-old patient with severe renal failure who had a rebound of dabigatran levels after idarucizumab, which necessitated additional hemodialysis and subsequent management with heparin [65]. In another case report, life-threatening gastrointestinal bleeding persisted after the administration of idarucizumab, such that additional supportive therapy, including emergent angiography and FEIBA administration, was warranted [66]. 
Overall, both dabigatran and idarucizumab play an important role in the treatment of thromboembolic disorders. While promising data exists, it is still imperative to monitor patients for bleeding events and check for early signs of toxicity in order to ensure the safety and effectiveness of both dabigatran and its specific reversal agent, idarucizumab.

\subsection{Factor Xa Inhibitors and Their Reversal}

The idea of developing an oral factor Xa inhibitor became prominent in the early 2000s, raising the hope of finding an agent for anticoagulation without the many adverse effects and drug interactions associated with warfarin [67]. Early success resulted in the approval of rivaroxaban and apixaban, around the same time as dabigatran [68]. At the time, there was no definitive advantage of using a factor Xa inhibitor over a direct thrombin inhibitor. They were simply different in terms of mechanism and biochemical properties [68].

Factor Xa inhibitors are small molecule drugs that bind directly to the active site of factor Xa, rendering it inactive. By inhibiting factor $\mathrm{Xa}$, a key component of the clotting cascade, the rest of the cascade ceases to progress. Bound factor $\mathrm{Xa}$ is unable to activate thrombin, ultimately preventing the formation of a clot (Figure 1).

\subsubsection{Rivaroxaban}

Rivaroxaban was the first factor Xa inhibitor approved by the USFDA. It binds reversibly and competitively to factor Xa with a selectivity that is 10,000 times higher than for other serine proteases without needing a cofactor $[69,70]$. Rivaroxaban has the ability to bind and inhibit both unbound factor $\mathrm{Xa}$ as well as clot-bound factor $\mathrm{Xa}$, ultimately preventing the formation of a thrombus. Multiple clinical trials (RECORD, EINSTEIN and ROCKET AF) evaluated rivaroxaban's effectiveness at preventing and treating a wide variety of thromboembolic disorders [71-76]. The RECORD 1 trials reported a significant reduction in the incidence of total VTE from $3.7 \%$ in the enoxaparin group to $1.1 \%$ in the rivaroxaban group, with an accompanying reduction in major VTE from $2 \%$ to $0.2 \%$, respectively. In the RECORD 2 trial, apart from a reduction in major VTE from $5.1 \%$ to $0.6 \%$, rivaroxaban showed $79 \%$ relative risk reduction compared to enoxaparin. In the RECORD 3 trial, all efficacy endpoints, primary and secondary, were reduced with total VTE reduction from $18.9 \%$ to $9.6 \%$ in the rivaroxaban group, compared to the enoxaparin group. In addition, there was $62 \%$ relative risk reduction associated with rivaroxaban use compared to enoxaparin. Similar superior effects were demonstrated in RECORD 4 with rivaroxaban showing more effectiveness in reducing total VTE from $10.1 \%$ to $6.9 \%$. The EINSTEIN trials compared the use of rivaroxaban in 1731 patients to enoxaparin/VKA in 1718 patients for acute DVT, where rivaroxaban showed non-inferior efficacy with regards to the primary outcomes. In the continued-treatment study, rivaroxaban had superior efficacy. ROCKET AF double-blind trials, conducted among 14,264 patients with NVAF, showed that rivaroxaban was non-inferior to warfarin in preventing stroke or systemic embolism. In 2011, rivaroxaban was approved in the US for VTE prophylaxis and treatment, prevention of stroke in patients with NVAF, and for reduction in the risk of major cardiovascular events in patients with coronary or peripheral artery disease [77].

Rivaroxaban has favorable pharmacokinetic and pharmacodynamics properties [78,79]. It is rapidly absorbed with a time to peak of about $2-4 \mathrm{~h}$, with estimated half-life of 5-9 h. Doses of $15 \mathrm{mg}$ or more should be taken with food, in order to maximize absorption, and dosing frequency is dependent upon the specific indication (either once or twice daily). Metabolism of rivaroxaban is carried out mainly by CYP3A4, while some of the unchanged drug is eliminated via the kidneys, facilitated by p-glycoprotein [80]. Rivaroxaban clearance is reduced in patients with renal impairment [81]. The involvement of both the liver and kidneys in rivaroxaban clearance is expected to decrease the risk for clinically significant drug interactions [82]. The major adverse effect of rivaroxaban is hemorrhage, with GI bleeds being the most common. The incidence of hemorrhage is reported to be $5-28 \%$, and major hemorrhage has been reported in $4 \%$ of patients or less [83]. 


\subsubsection{Apixaban}

Apixaban is a reversible direct factor Xa inhibitor, inhibiting both free and clot-bound factor Xa with a 30,000-fold selectivity compared to other coagulation proteases. It requires no co-factor and does not significantly impact platelet aggregation [84]. Apixaban demonstrated safety and efficacy in various clinical trials, including the ADVANCE, ARISTOTLE and AVERROES trials [85-88]. In the ADVANCE-1 randomized double-blind phase III trial, oral $2.5 \mathrm{mg}$ twice-daily apixaban was compared to $30 \mathrm{mg}$ subcutaneous twice-daily enoxaparin for the prophylaxis of VTE after total knee arthroplasty in 3195 patients. Apixaban was non-inferior to enoxaparin in efficacy outcome, but was superior in safety outcomes for major bleeding episodes. In the ADVANCE-2, a multicenter phase 3 trial, oral apixaban $2.5 \mathrm{mg}$ twice-daily was more effective than, and as safe (without increased bleeding) as $40 \mathrm{mg}$ once-daily subcutaneous enoxaparin in thromboprophylaxis after knee replacement surgery. In ADVANCE-3 trials, oral $2.5 \mathrm{mg}$ twice-daily enoxaparin was superior to $40 \mathrm{mg}$ once-daily subcutaneous enoxaparin for the prevention of all VTE, all-cause death, and major VTE in patients who have undergone total hip replacement. In the ARISTOTLE trial, apixaban was superior to warfarin in safety (reduced bleeding episodes) and the reduction of stroke, and systemic embolism in patients with atrial fibrillation. In the AVERROES trial, apixaban demonstrated superiority over aspirin in the prevention of stroke in patients with atrial fibrillation. The USFDA approved apixaban in 2012 for use in reducing the risk of stroke and systemic embolism in patients with NVAF. Its indication was expanded in 2014 by the USFDA to include the prevention of DVT and pulmonary embolism in people that had recently undergone knee or hip replacement.

Apixaban has predictable dose-dependent pharmacokinetics and can be taken without meals [89]. It is eliminated via a multiple route, which deceases its risk for drug-drug interaction [90-92].

\subsubsection{Edoxaban}

Edoxaban was approved in 2015 as the third factor Xa inhibitor. Apart from being as effective and well tolerated as apixaban and rivaroxaban, edoxaban offered the additional benefit of long half-life, allowing for a once-daily administration and the potential for better patient compliance [93]. Initial preclinical and clinical studies showed favorable safety profiles with dose range of 10-150 mg, with no dose-dependent adverse events [94-96]. As a substrate of P-glycoprotein and CYP3A4, edoxaban has the risk of drug interaction similar to rivaroxaban and apixaban [97,98]. Edoxaban can be taken without regard to food [99].

In the phase III trial, STARS J-V, edoxaban was superior to enoxaparin for the prevention of VTE in patients undergoing total hip arthroplasty in Japan [100]. In the ENGAGE AF-TIMI trial, a phase III trial of edoxaban in the United States, edoxaban was effective, and non-inferior to warfarin in patients with NVAF, with a significantly less incidence of bleeding and cardiovascular death [101]. The pivotal study that led to the approval of edoxaban was the HOKUSAI VTE trial. In this double-blind multicenter study, 8242 patients with acute VTE, who had been initially treated with heparin, were randomized to receive either edoxaban or warfarin for a period of 3 to 12 months. With respect to the primary efficacy outcome of recurrent symptomatic VTE (3.2\% in edoxaban vs. $3.5 \%$ in warfarin group), edoxaban was non-inferior to warfarin. With regards to the primary safety outcome measured by major or clinically relevant non-major bleeding, edoxaban was safer, with $8.5 \%$ outcome as against $10.3 \%$ with warfarin [102]. Hemorrhages, including dermal bleeding, GI bleeds, vaginal bleeding, and epistaxis are reportedly more frequent and severe with edoxaban [103]. Edoxaban has several USFDA boxed warnings, including increased risk of ischemic stroke in patients with NVAF who have a creatinine clearance above $95 \mathrm{~mL} / \mathrm{min}$, increased risk of ischemic events with premature discontinuation of edoxaban, and the occurrence of spinal or epidural hematomas in patients undergoing spinal puncture or neuraxial anesthesia. 


\subsubsection{Betrixaban}

Betrixaban is the fourth and newest addition to the growing list of factor Xa inhibitors following its approval by the USFDA in 2017. It has a more favorable pharmacokinetic profile with clearance independent of CYP-mediated metabolism, reducing the risk for drug metabolism [104-106]. With an onset of action and peak at around $3-4 \mathrm{~h}$, and a half-life of $19-27 \mathrm{~h}$, betrixaban is typically administered once daily.

In the phase II EXPERT trial, betrixaban demonstrated rapid and effective factor Xa inhibition with dose-dependent effectiveness in preventing VTE in patients undergoing total knee replacement surgery. Participants received a post-operative twice-daily oral betrixaban (15 or $40 \mathrm{mg}$ ) or $30 \mathrm{mg}$ subcutaneous twice-daily enoxaparin for 10 to 14 days. VTE incidence, the primary outcome of efficacy, was $20 \%$ in the $15 \mathrm{mg}$ betrixaban group, $15 \%$ in the $40 \mathrm{mg}$ betrixaban group, and $10 \%$ in the enoxaparin group. No major bleeds were reported in the betrixaban group with $2.3 \%$ in the enoxaparin group [107]. In another phase II trial, EXPLORE-Xa, betrixaban was compared to warfarin for stroke prevention in patients with atrial fibrillation [108]. The study reported similar bleeding rates between betrixaban and warfarin. However, the bleeding rates seemed to follow a dose-dependent manner as well, perhaps indicating that higher doses of betrixaban would translate to a higher risk of bleeding. In the phase III trial, APEX, extended duration betrixaban was not more effective than enoxaparin at preventing VTE [109].

Like other DOACs, the main adverse effects of betrixaban is bleeding (GI bleeding, intracranial hemorrhage, intraocular hemorrhage, hematuria, and epistaxis), reported in $1-2 \%$ of patients [110]. As a relatively new drug, data on the safety of betrixaban in various sub-populations is sparse. However, post-marketing clinical trials are ongoing. These include a current trial aimed to evaluate the pharmacokinetics, pharmacodynamics, and safety of betrixaban in pediatric population [111]. Another study, the BRAVO trial, is aimed to evaluate thrombotic and bleeding events due to betrixaban [112].

\subsubsection{Andexanet Alfa}

Although all four approved factor Xa inhibitors share the same mechanism of action and are considered safe, bleeding is still a major concern. The variations in their structures are believed to account for the differences in their pharmacokinetics profiles, which also impacts each of their unique indications [113]. In the development of andexanet as a reversal agent for factor Xa inhibitors, consideration was given for the possibility of having a single agent reverse the effect of multiple factor Xa inhibitors. Thus, unlike with dabigatran's reversal agent, idarucizumab, the use of monoclonal antibodies for reversing factor Xa inhibitors was not a plausible option [114].

Andexanet alfa (PRT064445, r-antidote), is an inactivated, recombinant form of human factor $X a$ and acts as a "decoy", mimicking the binding of factor Xa inhibitors [115]. Andexanet sequesters the factor Xa inhibitors and renders the drugs incapable of binding and inhibiting factor Xa, thereby reversing any anticoagulant effects [116-118]. Fondaparinux and LMWH enhance the action of antithrombin III, which inhibits both thrombin (factor II) and factor Xa. Andexanet competes against factor Xa for fondaparinux-activated or LMWH-activated antithrombin, which would free up more factor Xa to continue to propagate the clotting cascade, thereby partially reversing anticoagulant effects of fondaparinux and LMWH [119]. Additionally, andexanet has the ability to decrease tissue factor pathway inhibitor (TFPI) [120]. TFPI is a key regulator of the clotting cascade, which prevents excessive clotting. By decreasing TFPI, the clotting cascade leans towards thrombus formation. This may lead to thrombotic side effects, a phenomenon which would need to be examined with andexanet.

In preclinical trials, andexanet restored hemostasis in rat, mouse, and rabbit models [121,122]. In a "first-in-man" dose-ascending pharmacokinetic and pharmacodynamics phase I trial of andexanet in healthy volunteers, which was followed by in vitro anti-factor Xa activity assay, andexanet reversed thrombin generation and the anti-factor Xa activity of rivaroxaban in a dose-dependent manner [123]. A four-module phase II trial in healthy individuals tested the ability of varying doses of andexanet to reverse various anticoagulants; apixaban, rivaroxaban, enoxaparin, and edoxaban [124]. In the 
apixaban module, andexanet decreased the concentration of free apixaban, reduced anti-factor Xa activity, and re-established the generation of thrombin in a dose-dependent manner [125]. Similar effects were found in studies involving rivaroxaban, enoxaparin, and edoxaban, while andexanet decreased the unbound betrixaban concentrations, reducing anti-fXa (anti-factor Xa) activity, and restoring thrombin generation [126].

In two phase III trials, ANNEXA-A and ANNEXA-R, the ability of andexanet to reverse the effects of apixaban and rivaroxaban was examined. Patients in the ANNEXA-A study received $5 \mathrm{mg}$ of apixaban twice daily for 3.5 days, while patients in the ANNEXA-R study received $20 \mathrm{mg}$ rivaroxaban once daily for 4 days. Andexanet was administered $3 \mathrm{~h}$ after the last apixaban or placebo dose in the ANNEXA-A study, and andexanet was administered $4 \mathrm{~h}$ after the last rivaroxaban or placebo dose in the ANNEXA-R study. The primary outcome in both studies was the percent change in anti-factor-Xa activity from baseline (before administration of andexanet or placebo) to nadir ( 2 to $5 \mathrm{~min}$ after administration of andexanet or placebo). Secondary outcomes included number of participants with $>80 \%$ reduction in anti-fXa activity from baseline to nadir, change in free factor Xa inhibitor concentration from baseline to nadir, change in thrombin generation, and number of participants with thrombin generation above the lower limit of normal range. Participants included men and women between the age of 50 and 75 years, but excluded anyone who had a history of abnormal bleeding or thrombosis, active bleeding, adult asthma, use of inhaled medications, and those with risk factors for bleeding or thrombosis. Andexanet was found to reverse the anticoagulant effects of apixaban and rivaroxaban within two minutes of administration, an effect that was maintained for the duration of the infusion $[120,127]$. In the apixaban study, participants who received andexanet experienced a $94 \%$ reduction in anti-fXa activity, compared to $21 \%$ who received placebo. In the rivaroxaban study, participants who received andexanet experienced a $92 \%$ reduction in anti-fXa activity, compared to $18 \%$ who received placebo. Furthermore, both studies reported significant decrease in the concentration of unbound apixaban or rivaroxaban and both studies saw restoration of thrombin generation that had been inhibited by the factor Xa inhibitors. All participants who received the full dose of andexanet had $>80 \%$ reduction in anti-Xa activity. No significant adverse effects, including thrombosis, were reported. No antibodies against factor $X$ or Xa were detected in the trial participants [127]. There was a slight increase in D-dimer and prothrombin fragments $(\mathrm{F} 1+2)$ following andexanet administration, but the levels normalized within 24-72 $\mathrm{h}$. This could be explained by the inhibition of TFPI by andexanet, which would encourage clot formation. However, because these two markers are somewhat non-specific, an increase in levels does not always indicate pro-thrombosis.

Following the ANNEXA-A and ANNEXA-R studies, a phase III/IV trial, the ANNEXA-4 study, examined the reversal effects of andexanet on apixaban- or rivaroxaban-induced anticoagulation in cases of acute major bleeding [128]. The study evaluated 352 patients who had acute major bleeding within $18 \mathrm{~h}$ after rivaroxaban or apixaban administration. The trial had two primary outcomes: percent change in anti-fXa activity and percentage of participants with good or excellent hemostasis $12 \mathrm{~h}$ following andexanet infusion. Primary safety outcomes included rate of thrombosis, mortality rate, and antibody development. The results demonstrated that andexanet significantly decreased anti-Xa levels by $92 \%$ in both the rivaroxaban and apixaban groups, confirming a significant difference in one of the primary outcomes. The other primary outcome of excellent or good hemostasis was observed in $82 \%$ of patients $12 \mathrm{~h}$ after the end of the andexanet infusion. The study reported thrombotic events in $10 \%$ of the participants and a mortality rate of $14 \%$ within 30 days following the administration of andexanet. The high rate of thrombosis and mortality called for concern; however, it is important to note that all the patients included had a medical history significant for cardiovascular disorders, and the average age of the participants was 77 years, both factors that may explain the high thrombosis and mortality rates. This study confirmed the ability of andexanet to reduce anti-fXa activity caused by apixaban and rivaroxaban. This study also went a step further and examined andexanet in cases of acute major bleeding, which ultimately became one of andexanet's clinical indications. 
Following several of these favorable results, and being the first of its kind, andexanet received accelerated approval from the USFDA in May of 2018 for the specific indications of reversing rivaroxaban- and apixaban-related uncontrollable or life-threatening bleeding [129]. A year later (in April 2019), andexanet was approved in Europe for similar indications [130].

Andexanet is administered via intravenous infusion, and dosing depends on the dose of factor Xa inhibitor as well as the time since the factor Xa inhibitor was last administered (Figure 3). Low dose andexanet is $400 \mathrm{mg}$ IV bolus at $30 \mathrm{mg} / \mathrm{min}$, followed by $4 \mathrm{mg} / \mathrm{min}$ continuous IV infusion for up to $120 \mathrm{~min}$. High dose andexanet is $800 \mathrm{mg}$ IV bolus at $30 \mathrm{mg} / \mathrm{min}$, followed by $8 \mathrm{mg} / \mathrm{min}$ continuous IV infusion for up to $120 \mathrm{~min}$ (Table 2).

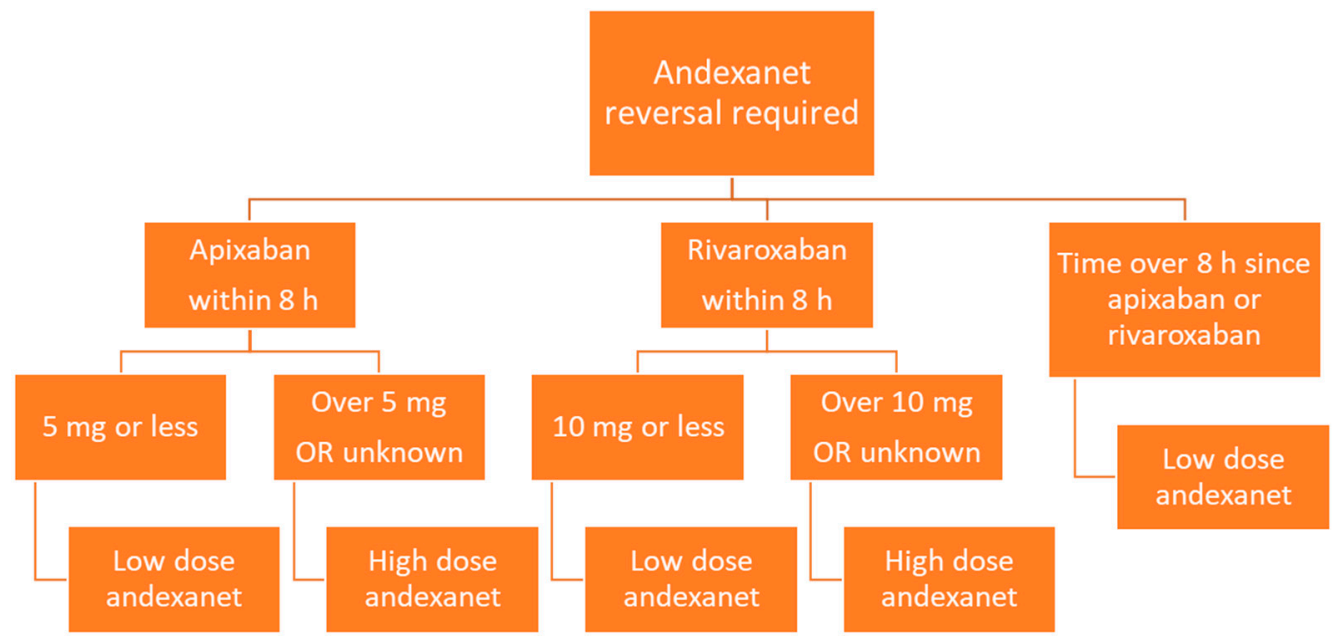

Figure 3. Flow diagram of andexanet dosing based on factor Xa inhibitor, dose, and time since last dose.

Table 2. Dosing of andexanet alfa.

\begin{tabular}{|c|c|c|}
\hline Administration & Low Dose & High Dose \\
\hline Bolus & $400 \mathrm{mg}$ at $30 \mathrm{mg} / \mathrm{min}$ & $800 \mathrm{mg}$ at $30 \mathrm{mg} / \mathrm{min}$ \\
\hline Infusion & $4 \mathrm{mg} / \mathrm{min}$ for $120 \mathrm{mins}$ & $8 \mathrm{mg} / \mathrm{min}$ for $120 \mathrm{mins}$ \\
\hline Number of vials & $\begin{array}{l}\text { Bolus }=400 \mathrm{mg} \rightarrow 4 \text { vials } \\
\text { Infusion }=480 \mathrm{mg} \rightarrow 5 \text { vials } \\
\text { Total }=9 \text { vials of } 100 \mathrm{mg}\end{array}$ & $\begin{array}{c}\text { Bolus }=800 \mathrm{mg} \rightarrow 8 \text { vials } \\
\text { Infusion }=960 \mathrm{mg} \rightarrow 10 \text { vials } \\
\text { Total }=18 \text { vials of } 100 \mathrm{mg} \\
\text { OR } 9 \text { vials of } 200 \mathrm{mg}\end{array}$ \\
\hline
\end{tabular}

Andexanet has favorable pharmacokinetic parameters, including a rapid onset of action of 2 min and a short half-life; a pharmacodynamic half-life of about 1 hour and the pharmacokinetic half-life of about 4.5-7.5 h [125,131-133]. Elimination pathways are not fully understood at this time.

The most common adverse effects associated with andexanet use include infusion reactions-with flushing and hot flashes being the most common-and antibody development. The reported antibodies produced were non-neutralizing and not considered to be of serious concern [125]. Some severe adverse effects related to andexanet's mechanism, reported during clinical trials, include deep vein thrombosis $(6 \%)$, ischemic stroke (5\%), acute myocardial infarction (3\%), pulmonary embolism (3\%), cardiogenic shock (2\%), and cardiac failure (1\%) [125]. Other unrelated adverse effects that were reported include pneumonia $(\geq 5 \%)$ and urinary tract infections $(\geq 5 \%)$. The FDA issued a box warning for the potential for thromboembolic events, ischemic risk, cardiac arrest, and sudden death. Due to the possibility of these serious adverse effects, the patients must be continually monitored.

While the approval of andexanet has brought about much excitement in the medical community, andexanet is only currently approved for the reversal of the bleeding caused by apixaban and rivaroxaban. This may be because of the lack of evidence to support its use in other factor Xa inhibitors, 
since edoxaban and betrixaban were very recently approved with limited andexanet-related studies. Regardless, due to its mechanism, andexanet may be able to reverse other anticoagulants as well, and future studies may lead to the expansion of its indications.

Along with being the only available specific reversal agent for apixaban and rivaroxaban, one other favorable aspect of andexanet is its rapid onset of action, which is desirable for halting active bleeding or achieving prompt reversal prior to an emergency surgery. By contrast, the severe adverse effects, short half-life, mechanism limitations, reconstitution time, and cost associated with andexanet use constitute major limitations in its clinical utility. Andexanet simply binds and sequesters factor Xa inhibitors; it does not induce or accelerate their clearance. This characteristic, along with its short half-life, may necessitate the requirement of multiple doses of the drug if the patient has not yet been stabilized by the time of andexanet's dissociation and degradation. Andexanet is currently priced at around $\$ 3,300$ per $100 \mathrm{mg}$, which would add up to a costly medical treatment of $\$ 29,700$ for the low dose and $\$ 59,400$ for the high dose. Another disadvantage is the time-consuming reconstitution process, which may be about $3-5 \mathrm{~min}$ per vial. Furthermore, reconstituted vials are stable for only $24 \mathrm{~h}$ in the refrigerator or $8 \mathrm{~h}$ at room temperature and prepared IV bags with andexanet are stable for only $16 \mathrm{~h}$ in the refrigerator or $8 \mathrm{~h}$ at room temperature, which prevents batch production of the drug for future use.

Andexanet is currently undergoing clinical development in Japan, and further clinical utilities are being explored [134]. Another phase II study that is expected to be completed by January 2020 is being conducted to examine the safety, tolerability, pharmacokinetics, and pharmacodynamics of andexanet in a population of healthy Japanese or Caucasian participants exposed to apixaban, rivaroxaban, edoxaban, or placebo [135]. A phase IV trial that started in January 2019 is currently examining the use of andexanet in patients with acute intracranial hemorrhage who are receiving an oral factor Xa inhibitor [136]. Additionally, the ANNEXA-4 extension study is still ongoing to examine the effects of andexanet in patients who have a major bleed while actively taking a factor Xa inhibitor, with the primary outcome being proportion of patients with excellent or good hemostasis $12 \mathrm{~h}$ after administration of andexanet [137].

Overall, as the first in its class, andexanet has the potential for expanded indication to reverse all factor Xa inhibitors.

\subsection{Reversal Agents in Development-Ciraparantag}

Ciraparantag, also known as aripazine or PER977, is a small, cationic, synthetic molecule that is being investigated as a potential 'universal antidote' to anticoagulants. While the exact pharmacological mechanism of action of ciraparantag is unclear, it is known to bind to various anticoagulant medications through non-covalent bonding, ultimately neutralizing their effects [138,139]. It has been shown to bind to unfractionated heparin, $\mathrm{LMWH}$, fondaparinux, direct thrombin inhibitors, and direct factor $\mathrm{Xa}$ inhibitors via charge-charge interactions and hydrogen bonding [140]. Ciraparantag does not appear to interfere with coagulation factors or other proteins involved in the clotting cascade [141].

Preclinical studies of ciraparantag have demonstrated safety in rats and dogs with no toxic effects on the cardiovascular, neurologic, or respiratory systems [142]. A study performed in DOAC-induced bleeding rat tails (using dabigatran, rivaroxaban, apixaban, or edoxaban) found that ciraparantag returned coagulation laboratory values to baseline within $20 \mathrm{~min}$, as well as decreased bleeding [143,144]. In human blood ex vivo, ciraparantag completely reversed both rivaroxaban and apixaban in a dose-dependent manner, measured by anti-Xa activity [145].

A single IV bolus dose (100-300 mg) of ciraparantag in healthy human subjects completely reversed edoxaban-induced anticoagulation within $10 \mathrm{~min}$, which was maintained for $24 \mathrm{~h}$ with no major adverse events [140]. A phase I/II trial of ciraparantag examined varying doses (100 mg, $200 \mathrm{mg}$, or $300 \mathrm{mg}$ ) in healthy volunteers treated with $1.5 \mathrm{mg} / \mathrm{kg}$ LMWH. Ciraparantag completely reversed the effects of LMWH within $20 \mathrm{~min}$ for the 100-mg dose and within $5 \mathrm{~min}$ for the 200-mg dose, with no thrombotic event or other serious adverse events reported [141]. 
While ciraparantag looks to be a promising reversal agent for all of the anticoagulant medications, much is still unknown about its pharmacokinetics and pharmacodynamics, as well as its effectiveness in humans. The FDA has granted fast track designation for the development of ciraparantag, and several clinical trials are underway (Table 3). 
Table 3. Clinical trials studying ciraparantag.

\begin{tabular}{|c|c|c|c|c|}
\hline $\begin{array}{l}\text { Clinical Trials } \\
\text { Identifier }\end{array}$ & Title & $\begin{array}{l}\text { Primary and Secondary } \\
\text { Outcomes }\end{array}$ & Status & $\begin{array}{l}\text { Results } \\
\text { Available? }\end{array}$ \\
\hline NCT01826266 & $\begin{array}{l}\text { Phase I Evaluation of the Safety, Tolerability, PK, and PD Effects } \\
\text { of a Double-Blind, Single Dose of PER977 Administered Alone, } \\
\text { and Following a Single Dose of Edoxaban }\end{array}$ & $\begin{array}{l}1^{\circ} \text { —safety, tolerability, plasma PK, and urinary PK of a } \\
\text { range of single IV doses of PER977 }\end{array}$ & $\begin{array}{c}\text { Completed } \\
\text { December } 2013\end{array}$ & No \\
\hline NCT02206100 & $\begin{array}{l}\text { Phase I/II Evaluation of the Safety, Tolerability, PK, and PD } \\
\text { Effects of Single, Hourly-Repeating Escalating Doses of PER977 } \\
\text { Following a Single Subcutaneous Dose of Enoxaparin }\end{array}$ & $\begin{array}{l}1^{\circ}-\text { number of adverse events } \\
2^{\circ} \text { - reversal of enoxaparin anticoagulation, PK of } \\
\text { enoxaparin, PK of PER977 and its metabolite }\end{array}$ & $\begin{array}{l}\text { Completed April } \\
2014\end{array}$ & No \\
\hline NCT02205905 & $\begin{array}{c}\text { An Open-label, Single-dose, Non-randomized Study of the } \\
\text { Absorption, Metabolism, and Excretion of Intravenously } \\
\text { Administered 14C-labeled PER977 in Healthy Male Subjects } \\
\text { (Phase I Study) }\end{array}$ & $\begin{array}{l}1^{\circ} \text {-characterization of the mass balance, metabolic } \\
\text { disposition, and identification of the metabolites and } \\
\text { general metabolic pathways } \\
\text { of PER977 } \\
2^{\circ} \text {-number of subjects with adverse events }\end{array}$ & $\begin{array}{l}\text { Completed August } \\
2014\end{array}$ & No \\
\hline NCT02207257 & $\begin{array}{l}\text { Phase II Randomized, Sequential Group, Evaluation of } \\
\text { Ascending Reversal Doses of PER977 Administered to Subjects } \\
\text { with Steady State Edoxaban Dosing and Re-anticoagulation } \\
\text { With Edoxaban Following PER977 Reversal }\end{array}$ & $\begin{array}{l}\text { 1'-WBCT as a measure of edoxaban anticoagulation } \\
\text { reversal by PER977 } \\
\text { 20_PK of PER977, PK of edoxaban administered with } \\
\text { PER977, safety coagulation measures, and safety and } \\
\text { tolerability of PER977 after edoxaban }\end{array}$ & $\begin{array}{c}\text { Completed } \\
\text { November } 2015\end{array}$ & No \\
\hline NCT02206087 & $\begin{array}{l}\text { Phase I/II Evaluation of the Safety, Tolerability, PK, and PD } \\
\text { Effects of a Single Escalating Dose of PER977 Following } \\
\text { Administration of Unfractionated Heparin }\end{array}$ & $\begin{array}{c}1^{\circ} \text { —effect of PER977 on reversal of UFH anticoagulation } \\
2^{\circ} \text { - safety and tolerability of PER977 administered } \\
\text { after UFH }\end{array}$ & $\begin{array}{l}\text { Completed March } \\
2016\end{array}$ & No \\
\hline NCT03288454 & $\begin{array}{l}\text { Phase } 2 \text { Placebo-Controlled, Single-Site, Single-Blind Study of } \\
\text { Apixaban Reversal by Ciraparantag as Measured by WBCT }\end{array}$ & $\begin{array}{c}1 \text { - efficacy of ciraparantag in reversal of } \\
\text { apixaban-induced anticoagulation, measured by WBCT } \\
2^{\circ} \text {-number of participants with abnormal lab values or } \\
\text { adverse events }\end{array}$ & $\begin{array}{l}\text { Recruiting; expected } \\
\text { to be complete in } \\
\text { January } 2019\end{array}$ & No \\
\hline NCT03172910 & $\begin{array}{l}\text { Phase } 2 \text { Placebo-Controlled, Single-Site, Single-Blind Study of } \\
\text { Rivaroxaban Reversal by Ciraparantag as Measured by WBCT }\end{array}$ & $\begin{array}{c}1^{\circ} \text {-efficacy of ciraparantag in reversal of } \\
\text { rivaroxaban-induced anticoagulation, measured by WBCT } \\
2^{\circ} \text {-incidence of adverse effects }\end{array}$ & $\begin{array}{l}\text { Recruiting; expected } \\
\text { to be complete in } \\
\text { January } 2019\end{array}$ & No \\
\hline
\end{tabular}




\section{Discussion}

DOACs have become a new class of therapeutic agents over the past 10 years, with increasing clinical utility for the prophylaxis and treatment of venous thromboembolism, as well as the prevention of stroke in NVAF. Data on the safety of these agents is sparse, leading many clinicians to be cautious in using them more extensively. Although studies have shown that these agents may present with less bleeding that warfarin, major bleeding is still the primary concern with their use. While warfarin-induced bleeding can easily be halted with the use of vitamin $\mathrm{K}$, the data in reversing DOAC-induced toxicity is limited, even with the relatively new approved reversal agents.

Warfarin is still widely used despite its many limitations, including the need to monitor INR. DOACs present with several advantages over traditional anticoagulants, including injectables. The predictability of their pharmacological effect and reliable dosing format without the need for monitoring are clinical merits that have made the DOACs preferable to clinicians and patients. Additionally, the non-reliance of DOACs on the CYP pathway for clearance presents an added advantage of reduced risk for drug-drug, food-drug, and herb-drug interactions compared to warfarin. Apart from the cost, the inability to reliably reverse the effect of DOACs has been known as the reason limiting their widespread use. Mild bleeds are less concerning and generally do not require intervention. Severe bleeding is associated with significant morbidity, and even mortality, if not treated immediately and effectively. Off-label use of PCC has been the mainstay of DOAC reversal, in addition to support measures.

Fortunately, extensive research has led to the development of two new antidotes as well as guidelines to direct practitioners should a hemorrhage event occur after the use of DOACs. The reversal agent for dabigatran, idarucizumab, and the reversal agent for rivaroxaban and apixaban, andexanet, brought about much excitement in the medical community. As being the first specific reversal agents for DOACs, these two agents have demonstrated efficacy and reliability, although, post-marketing data is still sparse.

\section{Conclusions}

A new generation of anticoagulants, DOACs, and their reversal agents are gaining prominence in cardiology. Physicians may reliably use DOACs with less concerns about the inability to control associated bleedings, as in the past. Post-marketing data on DOACs, idarucizumab, and andexanet will continue to provide guidance in this field, as DOACs are set to replace warfarin as first-line options in the prevention of venous thromboembolism. It is also exciting to envision the future of a universal reversal agent based on current research trajectory. In all, a lot of progress has been made in this field over the past decade.

Funding: This research received no external funding.

Conflicts of Interest: The authors declare no conflict of interest.

\section{References}

1. Serhal, M.; Barnes, G.D. Venous thromboembolism: A clinician update. Vasc. Med. 2019, 24, 122-131. [CrossRef] [PubMed]

2. Busch, M.; Masuhr, F. Thromboprophylaxis and early antithrombotic therapy in patients with acute ischemic stroke a37nd cerebral venous and sinus thrombosis. Eur. J. Med. Res. 2004, 9, 99-206.

3. Hirsh, J.; Warkentin, T.E.; Dalen, J.E.; Deykin, D.; Poller, L. Heparin: Mechanism of action, pharmacokinetics, dosing considerations, monitoring, efficacy, and safety. Chest 1995, 108, 258S-275S. [CrossRef] [PubMed]

4. Sokolowska, E.; Kalaska, B.; Miklosz, J.; Mogielnicki, A. The toxicology of heparin reversal with protamine: Past, present and future. Expert Opin. Drug Metab. Toxicol. 2016, 12, 897-909. [CrossRef] 
5. Lee, C.J.; Ansell, J.E. Direct thrombin inhibitors. Br. J. Clin. Pharmacol. 2011, 72, 581-592. [CrossRef]

6. Whitlon, D.S.; Sadowski, J.A.; Suttie, J.W. Mechanism of coumarin action: Significance of vitamin K epoxide reductase inhibition. Biochemistry 1978, 17, 1371-1377. [CrossRef]

7. Wadhera, R.K.; Russell, C.E.; Piazza, G. Warfarin versus novel oral anticoagulants: How to choose? Circulation 2014, 130, e191-e193. [CrossRef]

8. Yeh, C.H.; Gross, P.L.; Weitz, J.I. Evolving use of new oral anticoagulants for treatment of venous thromboembolism. Blood 2014, 124, 1020-1028. [CrossRef]

9. Mekaj, Y.H.; Mekaj, A.Y.; Duci, S.B.; Miftari, E.I. New oral anticoagulants: Their advantages and disadvantages compared with vitamin $\mathrm{K}$ antagonists in the prevention and treatment of patients with thromboembolic events. Ther. Clin. Risk Manag. 2015, 11, 967. [CrossRef]

10. Beyer-Westendorf, J.; Forster, K.; Pannach, S.; Ebertz, F.; Gelbricht, V.; Thieme, C.; Michalski, F.; Köhler, C.; Werth, S.; Sahin, K.; et al. Rates, management, and outcome of rivaroxaban bleeding in daily care: Results from the Dresden NOAC registry. Blood 2014, 124, 955-962. [CrossRef]

11. Castellucci, L.A.; Cameron, C.; Le Gal, G.; Rodger, M.A.; Coyle, D.; Wells, P.S.; Clifford, T.; Gandara, E.; Wells, G.; Carrier, M. Clinical and safety outcomes associated with treatment of acute venous thromboembolism: A systematic review and meta-analysis. JAMA 2014, 312, 1122-1135. [CrossRef] [PubMed]

12. Lip, G.Y.; Keshishian, A.; Kamble, S.; Pan, X.; Mardekian, J.; Horblyuk, R.; Hamilton, M. Real-world comparison of major bleeding risk among non-valvular atrial fibrillation patients initiated on apixaban, dabigatran, rivaroxaban, or warfarin. A propensity score matched analysis. Thromb. Haemost. 2016, 116, 975-986. [CrossRef]

13. Dabi, A.; Koutrouvelis, A.P. Reversal strategies for intracranial hemorrhage related to direct oral anticoagulant medications. Crit. Care Res. Pract. 2018, 2018, 4907164. [CrossRef] [PubMed]

14. Kaatz, S.; Kouides, P.A.; Garcia, D.A.; Spyropolous, A.C.; Crowther, M.; Douketis, J.D.; Chan, A.K.; James, A.; Moll, S.; Ortel, T.L.; et al. Guidance on the emergent reversal of oral thrombin and factor Xa inhibitors. Am. J. Hematol. 2012, 87, S141-S145. [CrossRef] [PubMed]

15. Steiner, T.; Böhm, M.; Dichgans, M.; Diener, H.C.; Ell, C.; Endres, M.; Epple, C.; Grond, M.; Laufs, U.; Nickenig, G.; et al. Recommendations for the emergency management of complications associated with the new direct oral anticoagulants (DOACs), apixaban, dabigatran and rivaroxaban. Clin. Res. Cardiol. 2013, 102, 399-412. [CrossRef]

16. Christos, S.; Naples, R. Anticoagulation reversal and treatment strategies in major bleeding: Update 2016. West. J. Emerg. Med. 2016, 17, 264. [CrossRef]

17. Levine, M.; Goldstein, J.N. Emergency reversal of anticoagulation: Novel agents. Curr. Neurol. Neurosci. Rep. 2014, 14, 471. [CrossRef]

18. Woo, J.S.; Kapadia, N.; Phanco, S.E.; Lynch, C.A. Positive outcome after intentional overdose of dabigatran. J. Med. Toxicol. 2013, 9, 192-195. [CrossRef]

19. van Ryn, J.; Ruehl, D.; Priepke, H.; Hauel, N.; Wienen, W. Reversibility of the anticoagulant effect of high doses of the direct thrombin inhibitor dabigatran, by recombinant Factor VIIa or activated prothrombin complex concentrate. Haemato Logica 2008, 93, S148.

20. Wang, X.; Mondal, S.; Wang, J.; Tirucherai, G.; Zhang, D.; Boyd, R.A.; Frost, C. Effect of activated charcoal on apixaban pharmacokinetics in healthy subjects. Am. J. Cardiovasc. Drugs 2014, 14, 147-154. [CrossRef]

21. Ollier, E.; Hodin, S.; Lanoiselée, J.; Escal, J.; Accassat, S.; De Magalhaes, E.; Basset, T.; Bertoletti, L.; Mismetti, P.; Delavenne, X. Effect of activated charcoal on rivaroxaban complex absorption. Clin. Pharm. 2017, 56, 793-801. [CrossRef] [PubMed]

22. Chen, B.C.; Sheth, N.R.; Dadzie, K.A.; Smith, S.W.; Nelson, L.S.; Hoffman, R.S.; Winchester, J.F. Hemodialysis for the treatment of pulmonary hemorrhage from dabigatran overdose. Am. J. Kidney Dis. 2013, 62, 591-594. [CrossRef] [PubMed]

23. Maw, T.T.; Henry, B.L.; Singh, T. Use of hemodialysis for the treatment of intracerebral hemorrhage in patients on dabigatran with normal renal function. Clin. Nephrol. Case Stud. 2014, 2, 18. [CrossRef] [PubMed]

24. Parasrampuria, D.A.; Marbury, T.; Matsushima, N.; Chen, S.; Wickremasingha, P.K.; He, L.; Dishy, V.; Brown, K.S. Pharmacokinetics, safety, and tolerability of edoxaban in end-stage renal disease subjects undergoing haemodialysis. Thromb. Haemost. 2015, 113, 719-727. 
25. Grandhi, R.; Newman, W.C.; Zhang, X.; Harrison, G.; Moran, C.; Okonkwo, D.O.; Ducruet, A.F. Administration of 4-factor prothrombin complex concentrate as an antidote for intracranial bleeding in patients taking direct factor Xa inhibitors. World Neurosurg. 2015, 84, 1956-1961. [CrossRef]

26. Schulman, S.; Ritchie, B.; Goy, J.K.; Nahirniak, S.; Almutawa, M.; Ghanny, S. Activated prothrombin complex concentrate for dabigatran-associated bleeding. Br. J. Haematol. 2014, 164, 308-310. [CrossRef]

27. Demeyere, R.; Gillardin, S.; Arnout, J.; Strengers, P.F. Comparison of fresh frozen plasma and prothrombin complex concentrate for the reversal of oral anticoagulants in patients undergoing cardiopulmonary bypass surgery: A randomized study. Vox Sang. 2010, 99, 251-260. [CrossRef]

28. Dumkow, L.E.; Voss, J.R.; Peters, M.; Jennings, D.L. Reversal of dabigatran-induced bleeding with a prothrombin complex concentrate and fresh frozen plasma. Am. J. Health Syst. Pharm. 2012, 69, 1646-1650. [CrossRef]

29. Cohen, H. Avoiding the misuse of fresh frozen plasma. BMJ 1993, 14, 307-395. [CrossRef]

30. Perzborn, E.; Heitmeier, S.; Laux, V.; Buchmüller, A. Reversal of rivaroxaban-induced anticoagulation with prothrombin complex concentrate, activated prothrombin complex concentrate and recombinant activated factor VII in vitro. Thromb. Res. 2014, 133, 671-681. [CrossRef]

31. Martin, A.C.; Le Bonniec, B.; Fischer, A.M.; Marchand-Leroux, C.; Gaussem, P.; Samama, C.M.; Godier, A. Evaluation of recombinant activated factor VII, prothrombin complex concentrate, and fibrinogen concentrate to reverse apixaban in a rabbit model of bleeding and thrombosis. Int. J. Cardiol. 2013, 168, 4228-4233. [CrossRef] [PubMed]

32. Harter, K.; Levine, M.; Henderson, S.O. Anticoagulation drug therapy: A review. West. J. Emerg. Med. 2015, 16, 11. [CrossRef] [PubMed]

33. Hunt, B.J. The current place of tranexamic acid in the management of bleeding. Anaesthesia 2015, 70, 50-e18. [CrossRef] [PubMed]

34. Moore, T.J.; Cohen, M.R.; Mattison, D.R. Dabigatran, bleeding, and the regulators. BMJ 2014, 349 , g4517. [CrossRef]

35. Stangier, J.; Rathgen, K.; Stähle, H.; Gansser, D.; Roth, W. The pharmacokinetics, pharmacodynamics and tolerability of dabigatran etexilate, a new oral direct thrombin inhibitor, in healthy male subjects. Br. J. Clin. Pharmacol. 2007, 64, 292-303. [CrossRef]

36. Trocóniz, I.F.; Tillmann, C.; Liesenfeld, K.H.; Schäfer, H.G.; Stangier, J. Population pharmacokinetic analysis of the new oral thrombin inhibitor dabigatran etexilate (BIBR 1048) in patients undergoing primary elective total hip replacement surgery. J. Clin. Pharmacol. 2007, 47, 371-382. [CrossRef]

37. Blech, S.; Ebner, T.; Ludwig-Schwellinger, E.; Stangier, J.; Roth, W. The metabolism and disposition of the oral direct thrombin inhibitor, dabigatran, in humans. Drug Metab. Dispos. 2008, 36, 386-399. [CrossRef]

38. Stangier, J.; Stähle, H.; Rathgen, K.; Fuhr, R. Pharmacokinetics and pharmacodynamics of the direct oral thrombin inhibitor dabigatran in healthy elderly subjects. Clin. Pharm. 2008, 47, 47-59. [CrossRef]

39. Alquwaizani, M.; Buckley, L.; Adams, C.; Fanikos, J. Anticoagulants: A review of the pharmacology, dosing, and complications. Curr. Emerg. Hosp. Med. Rep. 2013, 1, 83-97. [CrossRef]

40. Hankey, G.J.; Eikelboom, J.W. Dabigatran etexilate: A new oral thrombin inhibitor. Circulation 2011, 123, 1436-1450. [CrossRef]

41. Ebner, T.; Wagner, K.; Wienen, W. Dabigatran acylglucuronide, the major human metabolite of dabigatran: In vitro formation, stability, and pharmacological activity. Drug Metab. Dispos. 2010, 38, 1567-1575. [CrossRef] [PubMed]

42. Stangier, J.; Stähle, H.; Rathgen, K.; Roth, W.; Shakeri-Nejad, K. Pharmacokinetics and pharmacodynamics of dabigatran etexilate, an oral direct thrombin inhibitor, are not affected by moderate hepatic impairment. J. Clin. Pharmacol. 2008, 48, 1411-1419. [CrossRef] [PubMed]

43. Stangier, J.; Rathgen, K.; Stähle, H.; Mazur, D. Influence of renal impairment on the pharmacokinetics and pharmacodynamics of oral dabigatran etexilate. Clin. Pharm. 2010, 49, 259-268. [CrossRef] [PubMed]

44. Härtter, S.; Sennewald, R.; Nehmiz, G.; Reilly, P. Oral bioavailability of dabigatran etexilate (Pradaxa ${ }^{\circledR}$ ) after co-medication with verapamil in healthy subjects. Br. J. Clin. Pharmacol. 2013, 75, 1053-1062. [CrossRef]

45. Eriksson, B.I.; Dahl, O.E.; Ahnfelt, L.; Kälebo, P.; Stangier, J.; Nehmiz, G.; Hermansson, K.; Kohlbrenner, V. Dose escalating safety study of a new oral direct thrombin inhibitor, dabigatran etexilate, in patients undergoing total hip replacement: BISTRO I. J. Thromb. Haemost. 2004, 2, 1573-1580. [CrossRef] 
46. Beyer-Westendorf, J.; Ebertz, F.; Foerster, K.; Gelbricht, V.; Michalski, F.; Köhler, C.; Werth, S.; Endig, H.; Pannach, S.; Tittl, L.; et al. Effectiveness and safety of dabigatran therapy in daily-care patients with atrial fibrillation. Thromb. Haemost. 2015, 113, 1247-1257.

47. Southworth, M.R.; Reichman, M.E.; Unger, E.F. Dabigatran and postmarketing reports of bleeding. N. Engl. J. Med. 2013, 368, 1272-1274. [CrossRef]

48. Lillo-Le Louët, A.; Wolf, M.; Soufir, L.; Galbois, A.; Dumenil, A.S.; Offenstadt, G.; Samama, M.M. Life-threatening bleeding in four patients with an unusual excessive response to dabigatran: Implications for emergency surgery and resuscitation. Thromb. Haemost. 2012, 108, 583-585.

49. Enriquez, A.; Baranchuk, A.; Redfearn, D.; Simpson, C.; Abdollah, H.; Michael, K. Dabigatran for the prevention and treatment of thromboembolic disorders. Exp. Rev. Cardiovasc. Ther. 2015, 13, 529-540. [CrossRef]

50. Ganetsky, M.; Babu, K.M.; Salhanick, S.D.; Brown, R.S.; Boyer, E.W. Dabigatran: Review of pharmacology and management of bleeding complications of this novel oral anticoagulant. J. Med. Toxicol. 2011, 7, 281-287. [CrossRef]

51. Schiele, F.; van Ryn, J.; Newsome, C.; Sepulveda, E.; Park, J.; Nar, H.; Litzenburger, T. A specific antidote for dabigatran: Functional and structural characterization. Blood 2013, 121, 3554-3562. [CrossRef] [PubMed]

52. Glund, S.; Stangier, J.; Schmohl, M.; Moschetti, V.; Haazen, W.; De Smet, M.; Gansser, D.; Norris, S.; Lang, B.; Reilly, P. Idarucizumab, a specific antidote for dabigatran: Immediate, complete and sustained reversal of dabigatran induced anticoagulation in elderly and renally impaired subjects. Am. Soc. Hematol. 2014, 124, 344. [CrossRef]

53. Glund, S.; Stangier, J.; Schmohl, M.; Gansser, D.; Norris, S.; van Ryn, J.; Lang, B.; Ramael, S.; Moschetti, V.; Gruenenfelder, F.; et al. Safety, tolerability, and efficacy of idarucizumab for the reversal of the anticoagulant effect of dabigatran in healthy male volunteers: A randomised, placebo-controlled, double-blind phase 1 trial. Lancet 2015, 386, 680-690. [CrossRef]

54. Pollack, C.V., Jr.; Reilly, P.A.; Bernstein, R.; Dubiel, R.; Eikelboom, J.; Glund, S.; Huisman, M.V.; Hylek, E.; Kam, C.W.; Kamphuisen, P.W.; et al. Design and rationale for RE-VERSE AD: A phase 3 study of idarucizumab, a specific reversal agent for dabigatran. Thromb. Haemost. 2015, 114, 198-205.

55. Pollack, C.V., Jr.; Reilly, P.A.; Eikelboom, J.; Glund, S.; Verhamme, P.; Bernstein, R.A.; Dubiel, R.; Huisman, M.V.; Hylek, E.M.; Kamphuisen, P.W.; et al. Idarucizumab for dabigatran reversal. N. Engl. J. Med. 2015, 373, 511-520. [CrossRef]

56. Pollack, C.V., Jr.; Reilly, P.A.; Van Ryn, J.; Eikelboom, J.W.; Glund, S.; Bernstein, R.A.; Dubiel, R.; Huisman, M.V.; Hylek, E.M.; Kam, C.W.; et al. Idarucizumab for dabigatran reversal-Full cohort analysis. N. Engl. J. Med. 2017, 377, 431-441. [CrossRef]

57. Burness, C.B. Idarucizumab: First global approval. Drugs 2015, 75, 2155-2161. [CrossRef]

58. Tummala, R.; Kavtaradze, A.; Gupta, A.; Ghosh, R.K. Specific antidotes against direct oral anticoagulants: A comprehensive review of clinical trials data. Int. J. Cardiol. 2016, 214, 292-298. [CrossRef]

59. Eikelboom, J.W.; Quinlan, D.J.; van Ryn, J.; Weitz, J.I. Idarucizumab: The antidote for reversal of dabigatran. Circulation 2015, 132, 2412-2422. [CrossRef]

60. Hu, T.Y.; Vaidya, V.R.; Asirvatham, S.J. Reversing anticoagulant effects of novel oral anticoagulants: Role of ciraparantag, andexanet alfa, and idarucizumab. Vasc. Health Risk Manag. 2016, 2, 35.

61. Simon, A.; Domanovits, H.; Ay, C.; Sengoelge, G.; Levy, J.H.; Spiel, A.O. The recommended dose of idarucizumab may not always be sufficient for sustained reversal of dabigatran. J. Thromb. Haemost. 2017, 15, 1317-1321. [CrossRef] [PubMed]

62. Buchheit, J.; Reddy, P.; Connors, J.M. Idarucizumab (Praxbind) formulary review. Crit. Pathw. Cardiol. 2016, 15, 77-81. [CrossRef] [PubMed]

63. Yasaka, M.; Ikushima, I.; Harada, A.; Imazu, S.; Taniguchi, A.; Norris, S.; Gansser, D.; Stangier, J.; Schmohl, M.; Reilly, P.A. Safety, pharmacokinetics and pharmacodynamics of idarucizumab, a specific dabigatran reversal agent in healthy Japanese volunteers: A randomized study. Res. Pract. Thromb. Haemost. 2017, 1, 202-215. [CrossRef] [PubMed]

64. Steele, A.P.; Lee, J.A.; Dager, W.E. Incomplete dabigatran reversal with idarucizumab. Clin. Toxicol. 2018, 56, 216-218. [CrossRef] [PubMed] 
65. Stecher, A.; Vene, N.; Mavri, A.; Mijovski, M.B.; Krevel, B.; Gradišek, P. Late rebound of dabigatran levels after idarucizumab reversal in two patients with severe renal failure. Eur. J. Anaesthesiol. 2017, 34, 400-402. [CrossRef]

66. Alhashem, H.M.; Avendano, C.; Hayes, B.D.; Winters, M.E. Persistent life-threatening hemorrhage after administration of idarucizumab. Am. J. Emerg. Med. 2017, 35, 193. [CrossRef]

67. Misselwitz, F.; Berkowitz, S.D.; Perzborn, E. The discovery and development of rivaroxaban. Ann. N. Y. Acad. Sci. 2011, 1222, 64-75. [CrossRef]

68. Apostolakis, S.; Lip, G.Y.; Lane, D.A.; Shantsila, E. The quest for new anticoagulants: From clinical development to clinical practice. Cardiovasc. Ther. 2011, 29, e12-e22. [CrossRef]

69. Perzborn, E.; Strassburger, J.; Wilmen, A.; Pohlmann, J.; Roehrig, S.; Schlemmer, K.H.; Straub, A. In vitro and in vivo studies of the novel antithrombotic agent BAY 59-7939-An oral, direct Factor Xa inhibitor. J. Thromb. Haemost. 2005, 3, 514-521. [CrossRef]

70. Kubitza, D.; Becka, M.; Wensing, G.; Voith, B.; Zuehlsdorf, M. Safety, pharmacodynamics, and pharmacokinetics of BAY 59-7939-An oral, direct Factor Xa inhibitor-After multiple dosing in healthy male subjects. Eur. J. Clin. Pharmacol. 2005, 61, 873-880. [CrossRef]

71. Ageno, W. Rivaroxaban for the prevention of venous thromboembolism following major orthopedic surgery: The RECORD trials. Expert Rev. Cardiovasc. Ther. 2009, 7, 569-576. [CrossRef] [PubMed]

72. Turpie, A.G.; Lassen, M.R.; Davidson, B.L.; Bauer, K.A.; Gent, M.; Kwong, L.M.; Cushner, F.D.; Lotke, P.A.; Berkowitz, S.D.; Bandel, T.J.; et al. Rivaroxaban versus enoxaparin for thromboprophylaxis after total knee arthroplasty (RECORD4): A randomised trial. Lancet 2009, 373, 1673-1680. [CrossRef]

73. Romualdi, E.; Donadini, M.P.; Ageno, W. Oral rivaroxaban after symptomatic venous thromboembolism: The continued treatment study (EINSTEIN-extension study). Expert Rev. Cardiovasc. Ther. 2011, 9, 841-844. [CrossRef] [PubMed]

74. Prins, M.H.; Lensing, A.W.; Brighton, T.A.; Lyons, R.M.; Rehm, J.; Trajanovic, M.; Davidson, B.L.; Beyer-Westendorf, J.; Pap, Á.F.; Berkowitz, S.D.; et al. Oral rivaroxaban versus enoxaparin with vitamin $\mathrm{K}$ antagonist for the treatment of symptomatic venous thromboembolism in patients with cancer (EINSTEIN-DVT and EINSTEIN-PE): A pooled subgroup analysis of two randomised controlled trials. Lancet Haematol. 2014, 1, e37-e46. [CrossRef]

75. Pink, J.; Pirmohamed, M.; Hughes, D.A. Comparative effectiveness of dabigatran, rivaroxaban, apixaban, and warfarin in the management of patients with nonvalvular atrial fibrillation. Clin. Pharmacol. Ther. 2013, 94, 269-276. [CrossRef]

76. Rybak, I.; Ehle, M.; Buckley, L.; Fanikos, J. Efficacy and safety of novel anticoagulants compared with established agents. Ther. Adv. Hematol. 2011, 2, 175-195. [CrossRef] [PubMed]

77. Trujillo, T.; Dobesh, P.P. Clinical use of rivaroxaban: Pharmacokinetic and pharmacodynamic rationale for dosing regimens in different indications. Drugs 2014, 74, 1587-1603. [CrossRef]

78. Samama, M.M. The mechanism of action of rivaroxaban-an oral, direct Factor Xa inhibitor-compared with other anticoagulants. Thromb. Res. 2011, 127, 497-504. [CrossRef]

79. Kubitza, D.; Becka, M.; Voith, B.; Zuehlsdorf, M.; Wensing, G. Safety, pharmacodynamics, and pharmacokinetics of single doses of BAY 59-7939, an oral, direct factor Xa inhibitor. Clin. Pharmacol. Ther. 2005, 78, 412-421. [CrossRef]

80. Mueck, W.; Stampfuss, J.; Kubitza, D.; Becka, M. Clinical pharmacokinetic and pharmacodynamic profile of rivaroxaban. Clin. Pharm. 2014, 53,1-6. [CrossRef]

81. Kubitza, D.; Becka, M.; Mueck, W.; Halabi, A.; Maatouk, H.; Klause, N.; Lufft, V.; Wand, D.D.; Philipp, T.; Bruck, H. Effects of renal impairment on the pharmacokinetics, pharmacodynamics and safety of rivaroxaban, an oral, direct Factor Xa inhibitor. Br. J. Clin. Pharmacol. 2010, 70, 703-712. [CrossRef] [PubMed]

82. Weinz, C.; Schwarz, T.; Kubitza, D.; Mueck, W.; Lang, D. Metabolism and excretion of rivaroxaban, an oral, direct factor Xa inhibitor, in rats, dogs, and humans. Drug Metab. Dispos. 2009, 37, 1056-1064. [CrossRef] [PubMed]

83. Wasserlauf, G.; Grandi, S.M.; Filion, K.; Eisenberg, M.J. Meta-analysis of rivaroxaban and bleeding risk. Am. J. Cardiol. 2013, 112, 454-460. [CrossRef] [PubMed]

84. Wong, P.C.; Pinto, D.J.; Zhang, D. Preclinical discovery of apixaban, a direct and orally bioavailable factor Xa inhibitor. J. Throm. Thrombolysis 2011, 31, 478-492. [CrossRef] [PubMed] 
85. Lassen, M.R.; Raskob, G.E.; Gallus, A.; Pineo, G.; Chen, D.; Hornick, P. Apixaban versus enoxaparin for thromboprophylaxis after knee replacement (ADVANCE-2): A randomised double-blind trial. Lancet 2010, 375, 807-815. [CrossRef]

86. Lassen, M.R.; Gallus, A.S.; Pineo, G.F.; Raskob, G.E. Randomized double-blind comparison of apixaban with enoxaparin for thromboprophylaxis after knee replacement: The ADVANCE-1 trial. Blood 2008, 112, 31.

87. Easton, J.D.; Lopes, R.D.; Bahit, M.C.; Wojdyla, D.M.; Granger, C.B.; Wallentin, L.; Alings, M.; Goto, S.; Lewis, B.S.; Rosenqvist, M.; et al. Apixaban compared with warfarin in patients with atrial fibrillation and previous stroke or transient ischaemic attack: A subgroup analysis of the ARISTOTLE trial. Lancet Neurol. 2012, 11, 503-511. [CrossRef]

88. Diener, H.C.; Eikelboom, J.; Connolly, S.J.; Joyner, C.D.; Hart, R.G.; Lip, G.Y.; O’Donnell, M.; Hohnloser, S.H.; Hankey, G.J.; Shestakovska, O.; et al. Apixaban versus aspirin in patients with atrial fibrillation and previous stroke or transient ischaemic attack: A predefined subgroup analysis from AVERROES, a randomised trial. Lancet Neurol. 2012, 11, 225-231. [CrossRef]

89. Frost, C.; Nepal, S.; Wang, J.; Schuster, A.; Byon, W.; Boyd, R.A.; Yu, Z.; Shenker, A.; Barrett, Y.C.; Mosqueda-Garcia, R.; et al. Safety, pharmacokinetics and pharmacodynamics of multiple oral doses of apixaban, a factor $X$ a inhibitor, in healthy subjects. Br. J. Clin. Pharmacol. 2013, 76, 776-786. [CrossRef]

90. Raghavan, N.; Frost, C.E.; Yu, Z.; He, K.; Zhang, H.; Humphreys, W.G.; Pinto, D.; Chen, S.; Bonacorsi, S.; Wong, P.C.; et al. Apixaban metabolism and pharmacokinetics after oral administration to humans. Drug Metab. Dispos. 2009, 37, 74-81. [CrossRef]

91. Hanna, M.S.; Mohan, P.; Knabb, R.; Gupta, E.; Frost, C.; Lawrence, J.H. Development of apixaban: A novel anticoagulant for prevention of stroke in patients with atrial fibrillation. Ann. N. Y. Acad. Sci. 2014, 1329, 93-106. [CrossRef] [PubMed]

92. Hylek, E.M.; Held, C.; Alexander, J.H.; Lopes, R.D.; De Caterina, R.; Wojdyla, D.M.; Huber, K.; Jansky, P.; Steg, P.G.; Hanna, M.; et al. Major bleeding in patients with atrial fibrillation receiving apixaban or warfarin: The ARISTOTLE Trial (Apixaban for Reduction in Stroke and Other Thromboembolic Events in Atrial Fibrillation): Predictors, Characteristics, and Clinical Outcomes. J. Am. Coll. Cardiol. 2014, 63, 2141-2147. [CrossRef] [PubMed]

93. Schulman, S. Advantages and limitations of the new anticoagulants. J. Intern. Med. 2014, 275, 1-11. [CrossRef] [PubMed]

94. Samama, M.M.; Mendell, J.; Guinet, C.; Le Flem, L.; Kunitada, S. In vitro study of the anticoagulant effects of edoxaban and its effect on thrombin generation in comparison to fondaparinux. Thromb. Res. 2012, 129, e77-e82. [CrossRef] [PubMed]

95. Lip, G.Y.; Agnelli, G. Edoxaban: A focused review of its clinical pharmacology. Eur. Heart J. 2004, 35, 1844-1855. [CrossRef] [PubMed]

96. Ogata, K.; Mendell-Harary, J.; Tachibana, M.; Masumoto, H.; Oguma, T.; Kojima, M.; Kunitada, S. Clinical safety, tolerability, pharmacokinetics, and pharmacodynamics of the novel factor Xa inhibitor edoxaban in healthy volunteers. J. Clin. Pharmacol. 2010, 50, 743-753. [CrossRef]

97. Parasrampuria, D.A.; Truitt, K.E. Pharmacokinetics and pharmacodynamics of edoxaban, a non-vitamin K antagonist oral anticoagulant that inhibits clotting factor Xa. Clin. Pharm. 2016, 55, 641-655. [CrossRef]

98. Mikkaichi, T.; Yoshigae, Y.; Masumoto, H.; Imaoka, T.; Rozehnal, V.; Fischer, T.; Okudaira, N.; Izumi, T. Edoxaban transport via P-glycoprotein is a key factor for the drug's disposition. Drug Metab. Dispos. 2014, 42, 520-528. [CrossRef]

99. Mendell, J.; Tachibana, M.; Shi, M.; Kunitada, S. Effects of food on the pharmacokinetics of edoxaban, an oral direct factor Xa inhibitor, in healthy volunteers. J. Clin. Pharmacol. 2011, 51, 687-694. [CrossRef]

100. Fuji, T.; Fujita, S.; Kawai, Y.; Nakamura, M.; Kimura, T.; Fukuzawa, M.; Abe, K.; Tachibana, S. Efficacy and safety of edoxaban versus enoxaparin for the prevention of venous thromboembolism following total hip arthroplasty: STARS J-V. Thromb. J. 2015, 13, 27. [CrossRef]

101. Giugliano, R.P.; Ruff, C.T.; Braunwald, E.; Murphy, S.A.; Wiviott, S.D.; Halperin, J.L.; Waldo, A.L.; Ezekowitz, M.D.; Weitz, J.I.; Špinar, J.; et al. Edoxaban versus warfarin in patients with atrial fibrillation. N. Engl. J. Med. 2013, 369, 2093-2104. [CrossRef] [PubMed]

102. Hokusai-VTE Investigators. Edoxaban versus warfarin for the treatment of symptomatic venous thromboembolism. N. Engl. J. Med. 2013, 369, 1406-1415. [CrossRef] [PubMed] 
103. Chung, N.; Jeon, H.K.; Lien, L.M.; Lai, W.T.; Tse, H.F.; Chung, W.S.; Lee, T.H.; Chen, S.A. Safety of edoxaban, an oral factor Xa inhibitor, in Asian patients with non-valvular atrial fibrillation. Thromb. Haemost. 2011, 105, 535-545. [PubMed]

104. Palladino, M.; Merli, G.; Thomson, L. Evaluation of the oral direct factor Xa inhibitor-betrixaban. Expert Opin. Investig. Drugs 2013, 22, 1465-1472. [CrossRef]

105. Chan, N.C.; Hirsh, J.; Ginsberg, J.S.; Eikelboom, J.W. Betrixaban (PRT054021): Pharmacology, dose selection and clinical studies. Future Cardiol. 2014, 10, 43-52. [CrossRef]

106. Chan, N.C.; Bhagirath, V.; Eikelboom, J.W. Profile of betrixaban and its potential in the prevention and treatment of venous thromboembolism. Vasc. Health Risk Manag. 2015, 11, 343.

107. Turpie, A.G.; Bauer, K.A.; Davidson, B.L.; Fisher, W.D.; Gent, M.; Huo, M.H.; Sinha, U.; Gretler, D.D. EXPERT Study Group. A randomized evaluation of betrixaban, an oral factor Xa inhibitor, for prevention of thromboembolic events after total knee replacement (EXPERT). Thromb. Haemost. 2009, 101, 68-76.

108. Connolly, S.J.; Eikelboom, J.; Dorian, P.; Hohnloser, S.H.; Gretler, D.D.; Sinha, U.; Ezekowitz, M.D. Betrixaban compared with warfarin in patients with atrial fibrillation: Results of a phase 2, randomized, dose-ranging study (Explore-Xa). Eur. Heart J. 2013, 34, 1498-1505. [CrossRef]

109. Cohen, A.T.; Harrington, R.A.; Goldhaber, S.Z.; Hull, R.D.; Wiens, B.L.; Gold, A.; Hernandez, A.F.; Gibson, C.M. Extended thromboprophylaxis with betrixaban in acutely ill medical patients. N. Engl. J. Med. 2016, 375, 534-544. [CrossRef]

110. Gibson, C.M.; Halaby, R.; Korjian, S.; Daaboul, Y.; Arbetter, D.F.; Yee, M.K.; Goldhaber, S.Z.; Hull, R.; Hernandez, A.F.; Lu, S.P.; et al. The safety and efficacy of full-versus reduced-dose betrixaban in the Acute Medically Ill VTE (Venous Thromboembolism) Prevention With Extended-Duration Betrixaban (APEX) trial. Am. Heart J. 2017, 185, 93-100. [CrossRef]

111. U.S. National Library of Medicine. Available online: https://clinicaltrials.gov/ct2/show/NCT03346083?term= betrixaban\&rank=4 (accessed on 20 August 2019).

112. U.S. National Library of Medicine. Available online: https://linicaltrials.gov/ct2/show/NCT03613402 (accessed on 20 August 2019).

113. Steinberg, B.A.; Becker, R.C. Structure-function relationships of factor Xa inhibitors: Implications for the practicing clinician. J. Thromb. Thrombolysis 2014, 37, 234-241. [CrossRef] [PubMed]

114. Kaatz, S.; Bhansali, H.; Gibbs, J.; Lavender, R.; Mahan, C.E.; Paje, D.G. Reversing factor Xa inhibitors-clinical utility of andexanet alfa. J. Blood Med. 2017, 8, 141. [CrossRef] [PubMed]

115. Becker, R.C. The biochemistry, enzymology and pharmacology of non-vitamin K anticoagulant drug reversal agents and antidotes. J. Thromb. Thrombolysis 2016, 41, 273-278. [CrossRef] [PubMed]

116. Lu, G.; DeGuzman, F.R.; Hollenbach, S.J.; Karbarz, M.J.; Abe, K.; Lee, G.; Luan, P.; Hutchaleelaha, A.; Inagaki, M.; Conley, P.B.; et al. A specific antidote for reversal of anticoagulation by direct and indirect inhibitors of coagulation factor Xa. Nat. Med. 2013, 19, 446. [CrossRef]

117. Sartori, M.; Cosmi, B. Andexanet alfa to reverse the anticoagulant activity of factor Xa inhibitors: A review of design, development and potential place in therapy. J. Thromb. Thrombolysis 2018, 45, 345-352. [CrossRef]

118. Lu, G.; Lin, J.P.; Curnutte, J.T.; Conley, P.B. Effect of andexanet-TFPI interaction on in vitro thrombin formation and coagulation markers in the TF-pathway. Blood 2017, 130, 629.

119. Ghadimi, K.; Dombrowski, K.E.; Levy, J.H.; Welsby, I.J. Andexanet alfa for the reversal of Factor Xa inhibitor related anticoagulation. Expert Rev. Hematol. 2016, 9, 115-122. [CrossRef]

120. Siegal, D.M.; Curnutte, J.T.; Connolly, S.J.; Lu, G.; Conley, P.B.; Wiens, B.L.; Mathur, V.S.; Castillo, J.; Bronson, M.D.; Leeds, J.M.; et al. Andexanet alfa for the reversal of factor Xa inhibitor activity. N. Engl. J. Med. 2015, 373, 2413-2424. [CrossRef]

121. Yeh, C.H.; Fredenburgh, J.C.; Weitz, J.I. The real decoy: An antidote for factor Xa-directed anticoagulants. Circ. Res. 2013, 113, 954-957. [CrossRef]

122. Milling, T.J., Jr.; Ziebell, C.M. A review of reversal of oral anticoagulants, old and new, in major bleeding and the need for urgent surgery. Trends Cardiovasc. Med. 2019, in press. [CrossRef]

123. Crowther, M.; Kitt, M.; McClure, M.; Sinha, U.; Lu, G.; Karbarz, M.; Hutchaleelaha, A.; Barron, L.; Mathur, V.; Curnutte, J. Randomized, double-blind, placebo-controlled single ascending dose pharmacokinetic and pharmacodynamic study of PRT064445, a universal antidote for factor Xa inhibitors. Arter. Thromb. Vasc. Biol. 2013, 33, A10. 
124. U.S. National Library of Medicine. Available online: https:/clinicaltrials.gov/ct2/show/NCT01758432?term= andexanet\&rank=6 (accessed on 20 August 2019).

125. Siegal, D.; Lu, G.; Leeds, J.M.; Karbarz, M.; Castillo, J.; Mathur, V.; Hutchaleelaha, A.; Sinha, U.; Kitt, M.; McClure, M.; et al. Safety, pharmacokinetics, and reversal of apixaban anticoagulation with andexanet alfa. Blood Adv. 2017, 1, 1827-1838. [CrossRef] [PubMed]

126. Crowther, M.; Lu, G.; Conley, P.; Leeds, J.; Castillo, J.; Levy, G.; Connolly, S.; Curnutte, J. Reversal of factor XA inhibitors-induced anticoagulation in healthy subjects by andexanet alfa. Crit. Care Med. 2014, 42, A1469. [CrossRef]

127. Crowther, M.; Levy, G.; Lu, G.; Leeds, J.; Barron, L.; Conley, P. ANNEXA-A: A phase 3 randomized, double-blind, placebo-controlled trial, demonstrating reversal of apixaban-induced anticoagulation in older subjects by andexanet alfa (PRT064445), a universal antidote for factor Xa (fXa) inhibitors. Circulation 2014, 130, 2105-2126.

128. Connolly, S.J.; Crowther, M.; Eikelboom, J.W.; Gibson, C.M.; Curnutte, J.T.; Lawrence, J.H.; Yue, P.; Bronson, M.D.; Lu, G.; Conley, P.B.; et al. Full Study Report of Andexanet Alfa for Bleeding Associated with Factor Xa Inhibitors. N. Engl. J. Med. 2019, 380, 1326-1335. [CrossRef]

129. Heo, Y.A. Andexanet alfa: First global approval. Drugs 2018, 78, 1049-1055. [CrossRef]

130. Global News. Available online: http://www.globenewswire.com/news-release/2019/04/26/1810785/0/ en/European-Commission-Grants-Conditional-Marketing-Authorization-for-Portola-PharmaceuticalsOndexxya-andexanet-alfa-the-First-and-Only-Antidote-for-the-Reversal-of-Factor-Xa-Inhibit.html (accessed on 20 August 2019).

131. Cuker, A.; Burnett, A.; Triller, D.; Crowther, M.; Ansell, J.; Van Cott, E.M.; Wirth, D.; Kaatz, S. Reversal of direct oral anticoagulants: Guidance from the Anticoagulation Forum. Am. J. Hematol. 2019, 94, 697-709. [CrossRef]

132. Specialy Pharmacy Times. Available online: https://www.specialtypharmacytimes.com/news/fda-oks-largescale-commercial-production-of-andexxa (accessed on 20 August 2019).

133. Grottke, O.; Akman, N.; Braunschweig, T.; Conley, P.B.; Rossaint, R. Comparison of second and first generation of andexanet alfa in a porcine polytrauma model with apixaban anticoagulation. Blood 2018, 132, 3778. [CrossRef]

134. Ellington, T.M. A systematic and evidence-based review of published and pending reports of andexanet alfa. J. Pharm. Pract. 2019, in press. [CrossRef]

135. U.S. National Library of Medicine. Available online: https://clinicaltrials.gov/ct2/show/NCT03310021 (accessed on 20 August 2019).

136. U.S. National Library of Medicine. Available online: https://clinicaltrials.gov/ct2/show/NCT03661528 (accessed on 20 August 2019).

137. U.S. National Library of Medicine. Available online: https://clinicaltrials.gov/ct2/show/NCT02329327 (accessed on 20 August 2019).

138. Costin, J.; Ansell, J.; Laulicht, B.; Bakhru, S.; Steiner, S. Reversal agents in development for the new oral anticoagulants. Postgrad. Med. 2014, 126, 19-24. [CrossRef]

139. Milling, T.J., Jr.; Kaatz, S. Preclinical and clinical data for factor Xa and "universal" reversal agents. Am. J. Med. 2016, 129, S80-S88. [CrossRef] [PubMed]

140. Ansell, J.E.; Bakhru, S.H.; Laulicht, B.E.; Steiner, S.S.; Grosso, M.A.; Brown, K.; Dishy, V.; Lanz, H.J.; Mercuri, M.F.; Noveck, R.J.; et al. Single-dose ciraparantag safely and completely reverses anticoagulant effects of edoxaban. Thromb. Haemost. 2017, 117, 238-245. [CrossRef] [PubMed]

141. Costin, J.C.; Laulicht, B.; Bakhru, S.; Steiner, S. PER977 reverses low molecular weight heparin in addition to IIa and Xa new oral anticoagulants. J. Am. Coll. Cardiol. 2015, 65, A2056. [CrossRef]

142. Sullivan, D.W., Jr.; Gad, S.C.; Laulicht, B.; Bakhru, S.; Steiner, S. Nonclinical safety assessment of PER977: A small molecule reversal agent for new oral anticoagulants and heparins. Int. J. Toxicol. 2015, 34, 308-317. [CrossRef]

143. Bakhru, S.; Laulicht, B.; Jiang, X.; Chen, L.; Pan, D.; Grosso, M.; Morishima, Y.; Brown, K.; Masumoto, H.; Costin, J.; et al. PER977: A synthetic small molecule which reverses over-dosage and bleeding by the new oral anticoagulants. Circulation 2013, 128, A18809. 
144. Bakhru, S.; Laulicht, B.; Jiang, X.; Chen, L.; Grosso, M.; Morishima, Y.; Brown, K.; Mercuri, M.; Masumoto, H.; Costin, J.; et al. Reversal of anticoagulant-induced bleeding in external and internal bleeding models by PER977, a small molecule anticoagulant antidote. Circulation 2014, 130, A19361.

145. Laulicht, B.; Bakhru, S.; Bakhru, S.; Lee, C.; Baker, C.; Jiang, X.; Mathiowitz, E.; Costin, J. Small molecule antidote for anticoagulants. Circulation 2018, 126, A11395.

(c)

(C) 2019 by the authors. Licensee MDPI, Basel, Switzerland. This article is an open access article distributed under the terms and conditions of the Creative Commons Attribution (CC BY) license (http://creativecommons.org/licenses/by/4.0/). 